\title{
Chapter 6 \\ Changes of Tree and Stand Growth: Review and Implications
}

\author{
H. Pretzsch, M. del Río, F. Giammarchi, E. Uhl, and R. Tognetti
}

\begin{abstract}
In this chapter, we review the current long-term growth trends and shortterm growth reaction to single or repeated stress events on tree and stand level in Europe. Based on growth trend analyses, the chapter reveals the strong human footprint on forest ecosystems.

First, we use long-term experiments and increment cores to show change in growth trends within the last centuries. Growth reactions are caused by deposition and climate change rather than by silvicultural measures. Second, we look closer on regional-specific deviations from the general trend. Climate change, drought events, acid rain and $\mathrm{O}_{3}$ are causing regional-specific growth reaction patterns. Third, we assess stress events and the resilience and resistance of monospecific and mixed stands against biotic and abiotic stress in view of the ongoing growth trends.
\end{abstract}

\footnotetext{
H. Pretzsch $(\square)$

Forest Growth and Yield Science, TUM School of Life Sciences Weihenstephan, Technical University of Munich, Freising, Germany

e-mail: hans.pretzsch@tum.de

M. del Río

INIA, Forest Research Centre, Madrid, Spain

iuFOR, Sustainable Forest Management Research Institute, University of Valladolid \& INIA, Valladolid, Spain

e-mail: delrio@inia.es

F. Giammarchi

Faculty of Science and Technology, Free University of Bolzano-Bozen, Bolzano, Italy

e-mail: francesco.giammarchi@unibz.it

E. Uhl

Forest Growth and Yield Science, TUM School of Life Sciences Weihenstephan, Technical University of Munich, Freising, Germany

Bavarian State Institute of Forestry (LWF), Freising, Germany

e-mail: enno.uhl@tum.de

R. Tognetti

Dipartimento di Agricoltura, Ambiente e Alimenti, Università degli Studi del Molise,

Campobasso, Italy

e-mail: tognetti@unimol.it
} 
The revealed tree and stand growth behaviours are highly relevant, as any changes of forest growth and structure have strong impacts on the provision of goods and ecosystem services. The results underline the importance of biomonitoring and suggest counteracting measures by forest planning, adaptation of silvicultural guidelines for existing forest and innovative design of future forests stands.

\subsection{Introduction: The Information Potential of Tree and Stand Growth Trajectories}

At first sight, the reports about the status quo of forest health, vitality and productivity in Europe seem contradictory; on the one hand messages about growth acceleration (Kauppi et al. 2014), on the other hand forest dieback due to stress factors (Allen et al. 2015). The situation seems similarly contrary at the global level, with accelerating growth in the northern latitudes and growth decline in the Mediterranean and dry continental zones. At higher altitudes, the findings are similar to northern latitudes; some tree species in some regions seem to benefit from the changing environmental conditions, and other species in various regions suffer. In terms of canopy cover, European and North American forests have experienced a history of recovery (Nabuurs et al. 2013; Zhu et al. 2018). Climate change and land use changes interfere with forest regrowth, changing the temporal trajectories of biomass recovery and the age structure of forest stands. These forests, although continuing to sequester a significant amount of carbon, already show signs of growth saturation, which may limit their sink potential in the decades to come, as it will gradually saturate as trees age. Information on carbon uptake in regrowth forests derives from modelling exercises (Pugh et al. 2019). Sink saturation occurs due to a decrease in the assimilation component or an increase in the emission component for a given period of time. Global terrestrial carbon sink in forests is largely driven by tree physiological responses to increasing $\mathrm{CO}_{2}, \mathrm{~N}$ deposition, air pollution, evaporative demand, land use changes (vegetation shift, forest regrowth) and changes in forest cover (forest fire, forest dieback).

Certainly, the growth reaction pattern of a species depends on the respective site conditions and the specific environmental changes. When growing at its ecological optimum, i.e. in the centre of its realised ecological niche, a species will be less affected by environmental changes than when growing at the edge or even beyond its natural range. In Central Europe, a dieback of Norway spruce under drought in the lowlands beyond its natural range is not surprising. As it is not adapted to the increasing warmth and drought, the environmental conditions simply develop away from its ecological niche. Similarly, a growth acceleration of European beech in the mountain zone of the Alps and in its northern range area is not surprising as here the environmental conditions may improve the growing conditions of beech as they change towards its optimal growing conditions. A general increasing trend of basal area increment was observed for European beech throughout the twentieth century, across the Italian Peninsula, with the exception of southernmost populations (Tognetti et al. 2014), which was accompanied by a continuous enhancement in isotope-derived intrinsic water-use efficiency. 
In addition to the interplay between initial site conditions and large-scale environmental change, regional conditions may influence the growth behaviour. Examples for this are recovery from litter raking (Gimmi et al. 2013), soil acidification by deposition and over-exploitation (Lundström et al. 2003; Hoegberg et al. 2006), lowering of groundwater level (Pretzsch and Kölbel 1988), ozone exposure (Matyssek et al. 2010) or eutrophication by N deposition (Hofmann et al. 1990; Pretzsch et al. 2014a).

Yet, shifts of species' relative abundance in mixed-species forests might strongly affect regional carbon balances, which warrants the establishment/maintenance of long-term experiments to measure and monitor growth dynamics and trends in representative forests of major biogeographic areas (Pretzsch et al. 2019a). Water retention experiments, fertilizing experiments and other long-term experiments with different silvicultural treatments can reveal, for given site conditions and species setups, how the effects of environmental changes can be modulated or mitigated by management activities. They may contribute to answering whether tree species mixing, stand density reduction or choice of provenances can mitigate the effects of climate change, extending the present limit of forest carbon sink. Trees and forest stands may have the ability to acclimate to stress and to recover. Morphological acclimation and epigenetic adaptation to stress are far from being sufficiently understood. Due to the site dependency of growth behaviour, silvicultural recipes that are useful on one site may be inappropriate for counteracting environmental changes on other sites.

An important basis for fact-finding on growth reactions to external factors are long-term observations by, e.g. national inventory plots, environmental monitoring networks and networks of long-term experiments, covering extended environmental gradients. For the study at hand, we tapped these databases:

(i) To provide the theoretical basis for better understanding the spatial-temporal pattern of forest growth behaviour

(ii) To review and give overview of the growth trends and events of tree and stands in order to derive measures for silvicultural adaptation

(iii) To outline the process of acclimation to stress, adaptation and recovery

(iv) To discuss the implications of the revealed growth behaviour for environmental monitoring, forest ecology and management

\subsection{Theoretical Considerations on Growth Changes: Effects of Site Conditions and Species Identity}

\subsubsection{Standard of Comparison}

The unimodal relationship between environmental conditions and growth (or any other indicator of fitness) is helpful for understanding both the site-specific and nonlinear growth reactions of monocultures in case of disturbances (Tognetti et al. 2019) and the growth-stabilizing effect of tree species mixtures (Bauhus et al. 
growth

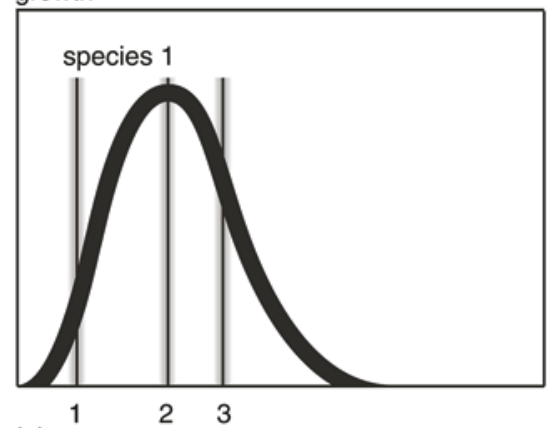

(a)

growth

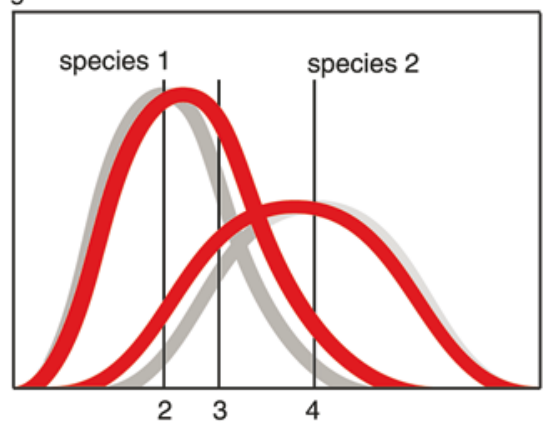

(c) growth

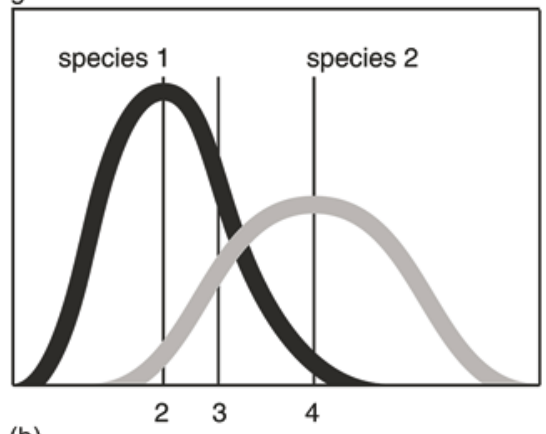

(b)

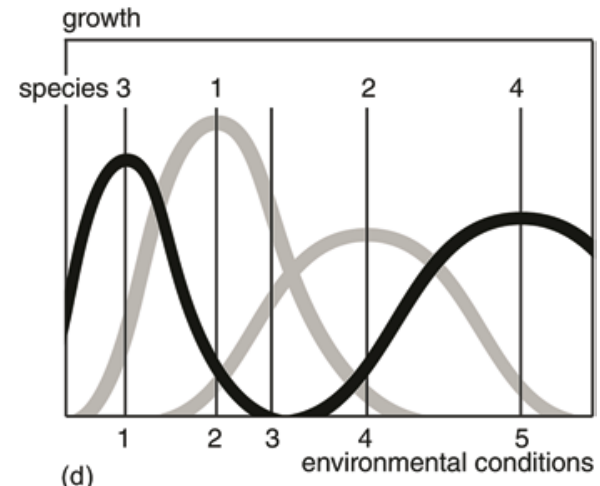

Fig. 6.1 Growth of various tree species depending on their realised ecological niche and prevailing site conditions in schematic representation. The vertical lines represent specific site conditions:

(a) Unimodal relationship between site conditions and growth of species 1. Any changes of site conditions (grey bands left and right to site conditions 1, 2 and 3) have stronger non-linear effects on sites 1 and 3 than on site 2

(b) Species 2 with a niche different from species 1 may compensate for growth losses when site conditions change from 2 to 3 or from 3 to 4

(c) Tree species interactions in mixed stands can extend (facilitation) or reduce (competition) the ecological niches of tree species (grey lines)

(d) By combining various tree species with different niches in mixtures (above numbers), stand growth under climate change (below numbers) may be stabilised

2017). In Figure 6.1a, the environmental conditions change along the $\mathrm{x}$-axis (for simplicity one dimensional); growth is high in the centre of the real niche and decreases if temperature, water and nutrient supply become scarce or excessive. Growth is rather stable under site condition 2 (see middle vertical line), as it is close to the saddle of the unimodal curve, where temporal variation of the resources supply (grey bands left and right of site 2) hardly changes the growth. However, on sites represented by the steep left or right branch of the niche, changes may have strong non-linear positive or negative effects (grey bands left and right of the sites 1 and 3 , left and right vertical lines). This is why climate warming by $2{ }^{\circ} \mathrm{C}$ may have hardly any effect on temperate sites but strong positive and negative effects on cold and warm sites, respectively. 
A combination of two species with differing niches, as shown in Figure 6.1b, may stabilise stand growth if site conditions change. In this case, species 2 may compensate for growth losses of species 1, if the site conditions shift from 2 to 3 or to 4 . Combining two species in a stand can also trigger competition reduction and facilitation (e.g. by hydraulic redistribution through hydraulic lift, atmospheric nitrogen fixation by symbionts) that may extend their real niche (grey unimodal curves in the background, Fig. 6.1c) and improve their growth stability (Fig. 6.1c).

Multispecies forest stands, as represented by their niche composition in Figure 6.1d, may be inferior in growth under stable environmental conditions as some species are growing suboptimally. However, if the environmental conditions change, e.g. gradually to a warmer and drier climate, or episodically caused by drought years, this may change. In this case an assemblage of various tree species with different niches can mean a risk distribution and stabilisation of stand productivity, although one or the other tree species may decline or even drop out.

\subsubsection{Long- and Short-Term Deviations from Normality}

Useful references for detection of any trend or event of the tree or stand development are basic growth and yield curves as shown in Figure 6.2a. Under constant environmental conditions, the growth has a unimodal development over time, and the yield, as the integral of the growth, has a sigmoid shape. With progressing size, tree and stand growth declines, and the yield curve has an asymptotic course. Marziliano et al. (2019) observed that the increase in tree size, more than senescence, explained the reduction in height increment in older silver fir trees. Certainly, the growth and yield curves of diameter, basal area and volume differ in rhythm (slope, point of inflexion, turning point), and they are also species specific and depend, among others, on site conditions, but the unimodal pattern and sigmoid shape remain as their general characteristics and can be used as reference for detecting abnormal developments in case of environmental changes.

Based on the unimodal growth curve (black) as a standard of comparison, any acceleration or deceleration of growth by environmental changes (Fig. 6.2b) with improved growing conditions may be interrupted by episodic stress events (Fig. 6.2c), or normal growing conditions terminated by stress events with short- or long-lasting growth reduction (Fig. 6.2d) can be revealed and quantified.

\subsection{Empirical Evidence of Growth Trends and Events}

\subsubsection{Overarching Growth Trends in the Lowlands of Europe}

Shortly after the acid rain phenomena from 1970 to 1980, Kenk et al. (1991) detected a site index improvement by up to 7 metres of dominant height at age 100 according to the yield table by Assmann and Franz (1963) for Norway spruce stands on poor 
growth

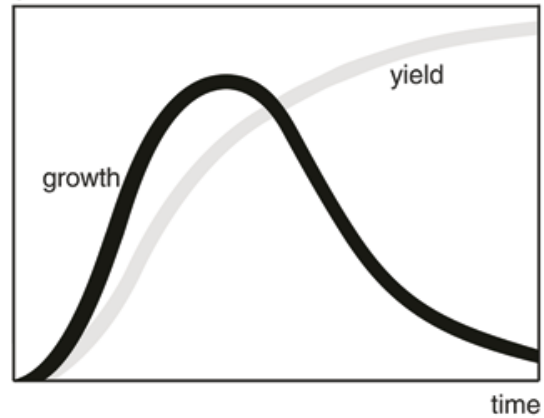

(a)

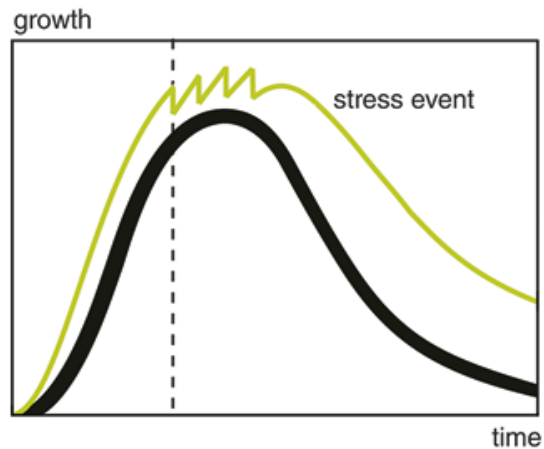

(c)

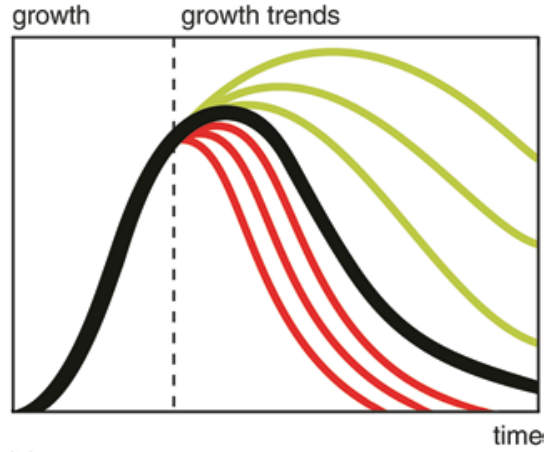

(b)

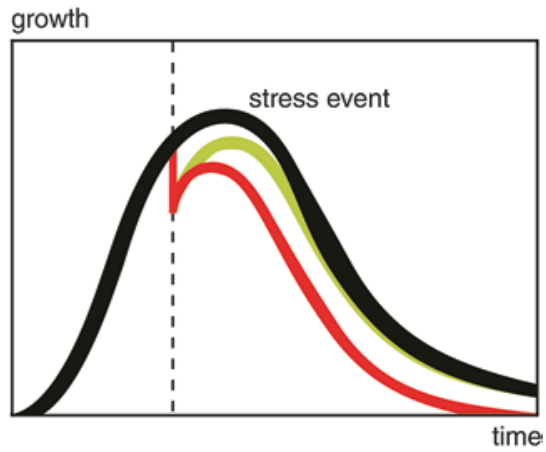

(d)

Fig. 6.2 Modification of the normal unimodal growth curve (black) of forest trees or even-aged forest stands by changing environmental conditions. (a) Unimodal curve of tree and stand growth (integrated yield in grey) under normal, constant and undisturbed growing conditions. (b) Acceleration (green) or deceleration (red) of growth caused by environmental changes. (c) Improved growing conditions, interrupted by episodic stress events (green). (d) Normal growing conditions, halted by stress events with subsequent low (red) and high (green) resilient reaction

and medium sites. Among others, Spiecker et al. (1996), Bontemps et al. (2012), Kauppi et al. (2014) and Pretzsch et al. (2014a) revealed that forest stand growth dynamics in most parts of Europe have strongly accelerated in recent decades.

Pretzsch et al. (2019a) compiled a data set of several hundred long-term experiments from Austria, Denmark, France, Germany, Great Britain, Poland, Spain, Sweden and Switzerland for closer analyses of the current growth trends in European lowlands. Figure 6.3 shows the total stand volume production of 577 fully stocked and unthinned or just moderately thinned long-term experiments of Norway spruce, Scots pine, European beech and common and sessile oak in comparison to the yield tables for Norway spruce by Wiedemann (1936/1942), Scots pine by Wiedemann (1943), European beech by Schober (1967) and sessile oak by Jüttner (1955). The yield classes I and IV of these tables represent the development of the respective species growing in the early twentieth century under optimal and poor conditions, respectively. 

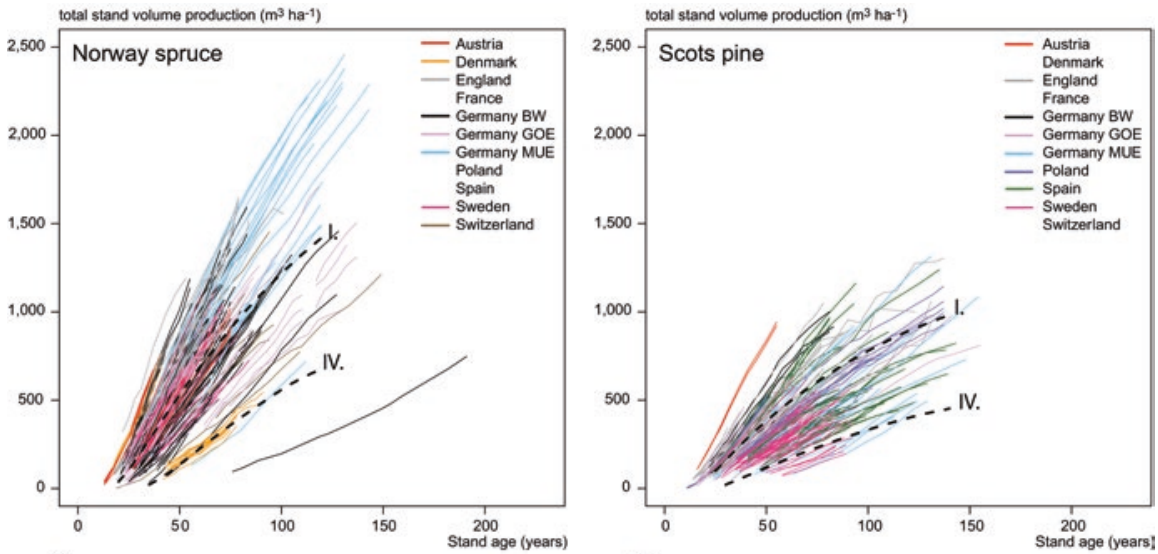

(a)

(b)
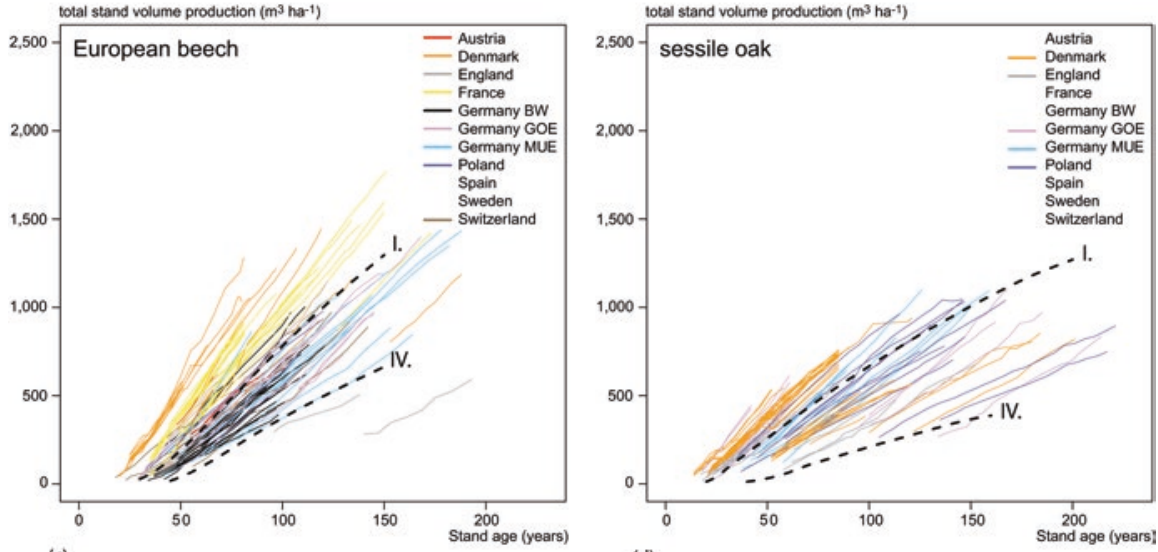

(c)

(d)

Fig. 6.3 Development of the total volume production on long-term experiments of (a) Norway spruce $(n=202)$, (b) Scots pine $(n=189)$, (c) European beech $(n=97)$ and (d) sessile oak $(n=89)$ in Europe established between 1848 and 2010, according to Pretzsch et al. (2019a). The observed trajectories strongly exceed the spectrum of common yield tables (yield classes I and IV) for Norway spruce by Wiedemann (1936/1942), Scots pine by Wiedemann (1943), European beech by Schober (1967) and sessile oak by Jüttner (1955). The German experimental plots were provided by the Forest Research Station of Baden-Württemberg (BW), the Research Station of Lower Saxony in Goettingen (GOE) and the Chair for Forest Growth and Yield Science at TUM in München (MUE)

The same data set also revealed significant relocations of the age trajectories of total stand volume production and related variables when considering the year of stand establishment. Figure 6.4 shows, representatively for Scots pine, how the total stand volume production, standing volume and absolute and relative cumulative volume, achieved at a given age, changed during the last 150 years. Similar trends were found for other major species. The total stand production and standing stock in a mature Scots pine stand is reached 50 years earlier today than for stands that 


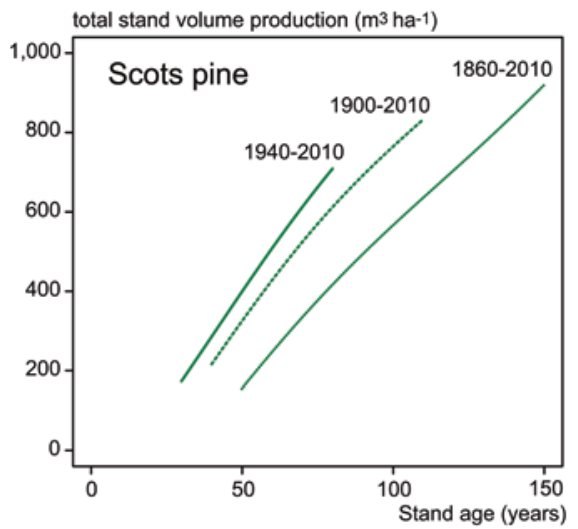

(a)

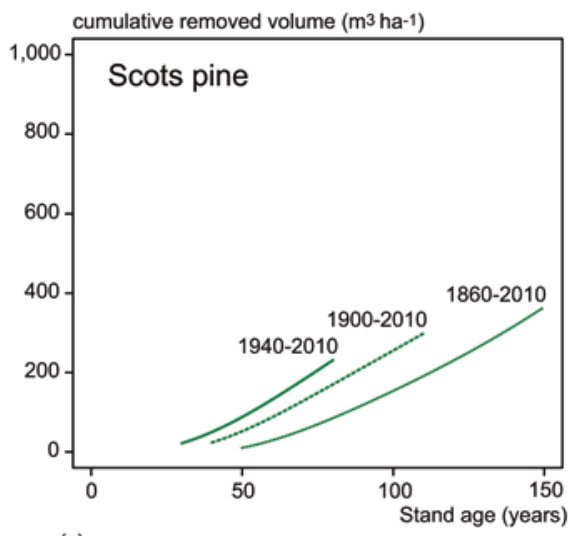

(c)

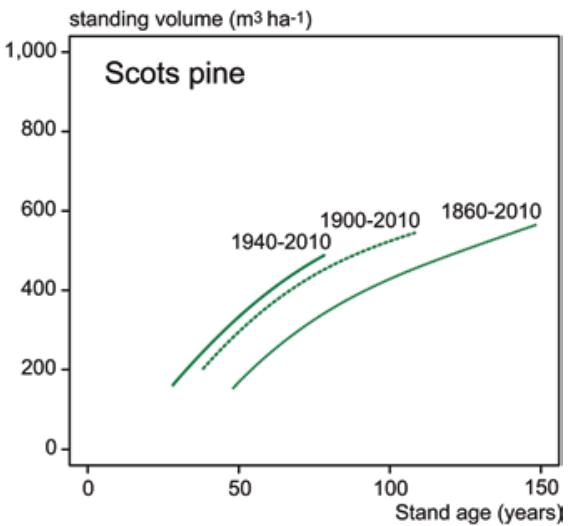

(b)

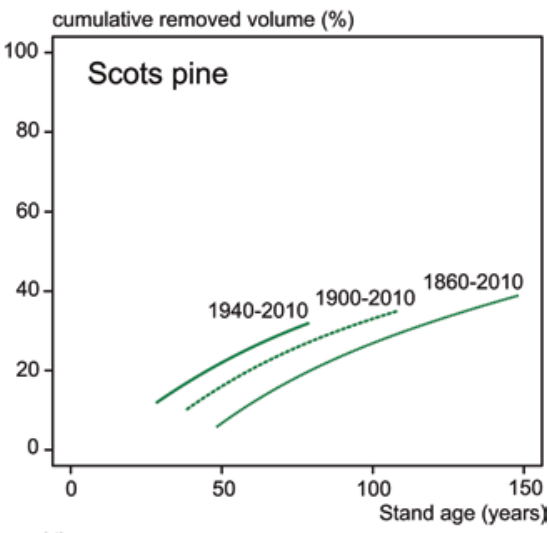

(d)

Fig. 6.4 Change of (a) total stand volume production, (b) standing volume, (c) cumulative removed volume and (d) percentage of removed (mortality, thinning) volume of fully stocked, unthinned or just moderately thinned long-term experiments of Scots pine established in 1860, 1900 and 1940, according to Pretzsch et al. (2019a)

were established 100 years earlier. As a consequence, the intermediate yield (i.e. the cumulative removed volume) is $200 \mathrm{~m}^{3} \mathrm{ha}^{-1}$ at the age of 75 years at present, while it was just $75 \mathrm{~m}^{3} \mathrm{ha}^{-1}$ for stands that were established 100 years earlier. This reflects an increase by $150 \%$. The cumulative removed volume is the total production minus standing volume; the percentage of removed volume results from (total production - standing volume)/total production $\times 100$.

For a subsample of the plots in Germany, Pretzsch et al. (2018) showed that wood density decreased by $8-12 \%$ since 1900 . Even if stand and trees grew much faster in terms of wood volume, stand biomass increment increased by 9-24 percentage points less compared to volume increment. This does not at all cancel the remarkable volume growth acceleration in the past 100 years, but it slightly reduces the findings based on stand volume records. The decreasing wood density goes 
along with an increased early wood fraction and points to the observed extension of the growing season and fertilisation effect of dry deposition as the main causes of the detected changes in growth trends.

The growth trends shown in Figures 6.3 and 6.4 indicate changes in growth conditions in terms of rising temperature, extension of the growing season, rising atmospheric $\mathrm{CO}_{2}$ level, nitrogen deposition and abandonment of nutrient-exporting treatments such as litter raking (Pretzsch et al. 2014a). In other regions, environmental changes can be, of course, also detrimental for growth rates and slow down stand dynamics. A recent study about tree growth in forests and urban areas revealed that the beneficial effects of climate change can turn into growth decrease and losses in regions with limited water and nutrient availability (Pretzsch et al. 2017). Again, without unmanaged long-term experiments, the knowledge of growth trends and their causes would be strongly biased or blurred. Nevertheless, Keenan et al. (2016), using global carbon budget estimates, ground, atmospheric and satellite observations, and multiple global vegetation models, reported increases in the terrestrial sink during the past decade. This was associated with the effects of rising atmospheric $\mathrm{CO}_{2}$, though many other factors may influence the carbon cycle at the local scale. Indeed, partitioning of photosynthates can be largely influenced by environmental factors, stand age and forest management.

\subsubsection{Growth Trends in High-Elevation Forest Ecosystems}

High-altitude forest ecosystems often provide invaluable ecosystem services, e.g. protection against avalanches, landslides, rockfall or flooding (Bebi et al. 2001). Due to their prevailing limitation by low temperatures and short growing season, especially mixed mountain forest ecosystems at higher elevations are expected to be strongly affected by climate warming (Piao et al. 2011; Vayreda et al. 2012; RuizBenito et al. 2014) similarly to forest ecosystems in the northern latitudes. Knowledge of any growth trends or structural changes of mountain forests may enable forest management to adapt and stabilise these stands and thus avoid decline of productivity and other forest ecosystem services.

Hilmers et al. (2019) and Pretzsch et al. (2020b) showed, for mixed mountain forest of Norway spruce (Picea abies (L.) Karst.), silver fir (Abies alba Mill.) and European beech (Fagus sylvatica L.), how environmental changes can modify the growth trend of tree species, depending on the altitude. The revealed altitudinalrelated growth trends were found in European mixed mountain forests but probably show reaction patterns that may be characteristic for forest ecosystems at higher elevations under environmental change.

Pretzsch et al. (2020b) sampled increment cores from 1721 Norway spruces, silver firs and European beeches on 28 long-term experimental plots in mixedmountain forest, in seven European countries from Bulgaria to Switzerland. The plots were located between 621 and $1569 \mathrm{~m}$ a.s.l., having an annual temperature range between 2.9 and $8.2{ }^{\circ} \mathrm{C}$ and an annual precipitation of 794-2767 $\mathrm{mm} \mathrm{yr}^{-1}$. 


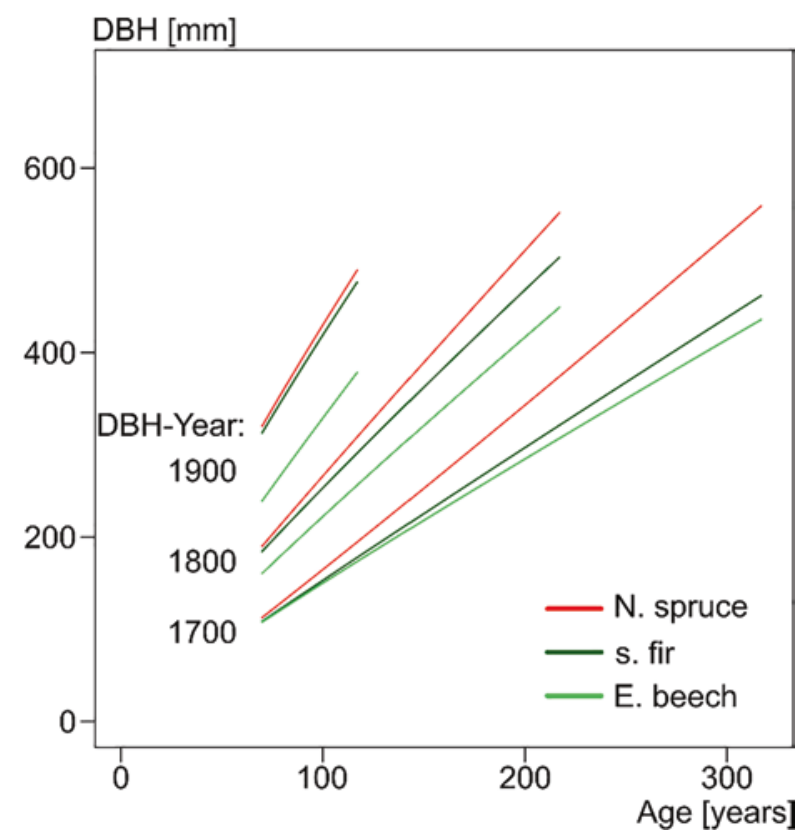

Fig. 6.5 Overview of the changes in the level and steepness of the growth curves of Norway spruce, silver fir and European beech during the last three centuries, according to Pretzsch et al. (2020b). For all the three species, the steepness of the curve increased the strongest in the case of European beech and silver fir and the least in the case of Norway spruce

The tree ring series revealed an increase of both the level and the slope of the diameter-age relationship for all the three species during the last 300 years, as shown in Figure 6.5. The trend of steepening the diameter-age relationship from year 1700 to the present is strongest for silver fir and European beech and the least pronounced for Norway spruce. In the past (1700), the size growth of Norway spruce was far ahead of silver fir and European beech, whereas, in the two recent centuries, the slopes of the growth curves of silver fir and European beech increased, indicating a trend to a more similar growth vigour.

For Norway spruce, the change in growth trend was not dependent on altitude (Fig. 6.6a), but, for silver fir (not shown) and especially for European beech (Fig. 6.6b), we found an altitude-dependent behaviour. In the past (DBH-year 1700), the growth of silver fir and European beech was the highest at low altitudes and the lowest at high elevations. Both species changed this pattern from 1700 until present. Trees with DBH-year 1900 are growing better at high elevations and less at lower altitudes.

This spatio-temporal pattern suggests temperature increase as the main factor for significant changes in the growth and interspecific competition at the expense of Norway spruce in mixed mountain forests. The long-term growth trajectories of Norway spruce in relation to silver fir and European beech hint at a relative advantage of fir and beech at the expense of spruce. The relative inferior growth trend of spruce in relation to fir and beech corresponds to a loss of fitness. On the long run, 

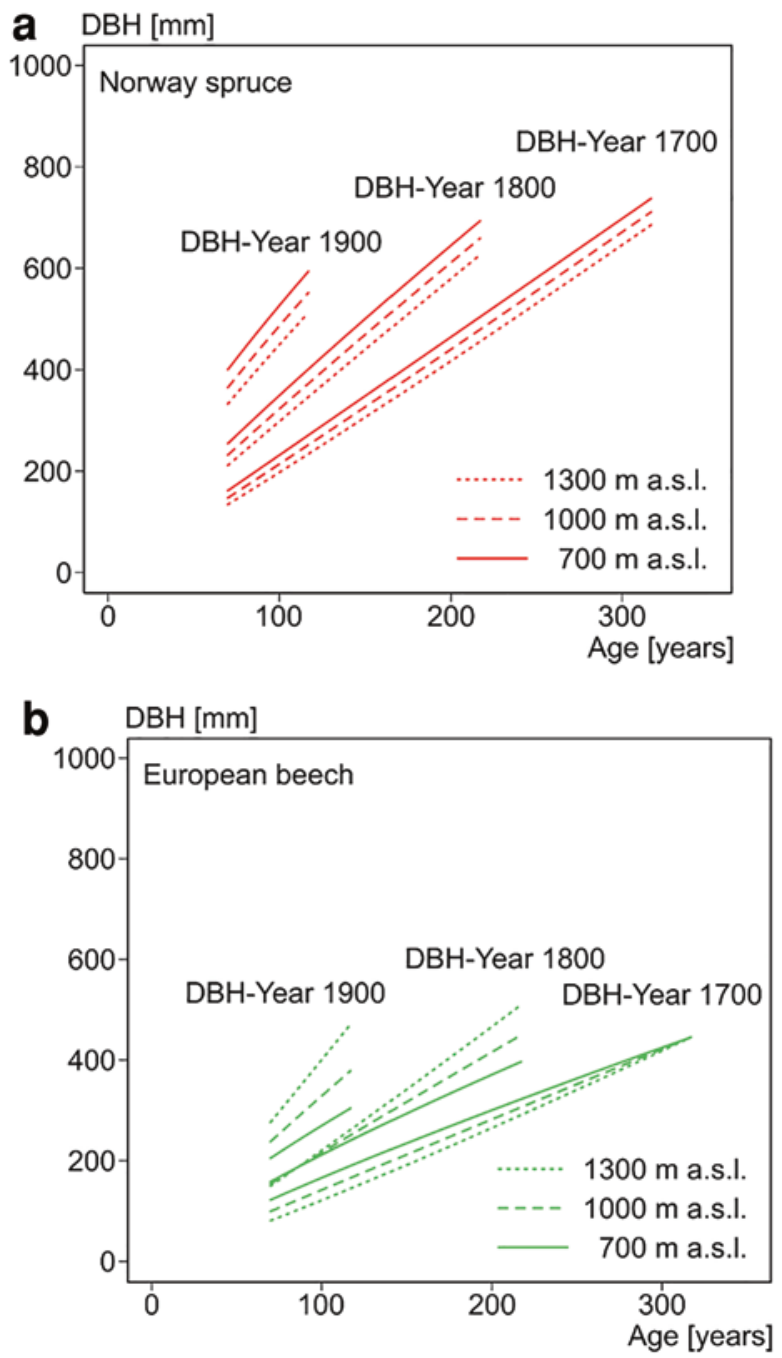

Fig. 6.6 Altitude-dependent changes of the growth of (a) Norway spruce and European beech (b) in the last 300 years, according to Pretzsch et al. (2020b). (a) In the case of Norway spruce, the growth was the highest at lower elevations and decreased with altitude in the past (DBH-year 1700 and 1800) as well as at present. (b) In the case of European beech, the growth was also the highest at lower elevations and decreased with altitude in the past. During the last 200 years, the relationships turned to a superior growth at higher altitudes compared to lower elevations

this may reduce the competitive strength and success of Norway spruce in stand development and natural regeneration.

Similar altitude-dependent temporal changes were found when analysing intraspecific synchrony in tree growth response to inter-annual fluctuations during the last century (del Río et al. 2020). Synchrony within beeches decreased with climate warming at high altitudes, reflecting a lower dependency of climate conditions in the last decades. By contrast, Norway spruce synchrony maintained constant at high 
altitudes but increased remarkably at lower altitudes, indicating that climate warming is exerting a stronger control on spruce growth at these altitudes.

At lower altitudes, Norway spruce is endangered especially by drought stress and subsequent bark beetle infestation; at higher altitudes, it is impaired by the growth acceleration of competing silver fir and European beech in mixed mountain stands. The climate change-induced promotion of silver fir and European beech will, in absence of silvicultural activities, gradually replace the role that Norway spruce had in the past in the high-montane and subalpine zone. At lower altitudes, Norway spruce will be limited to cold sites in hollow relief where silver fir and European beech, but not Norway spruce, suffer from late frost.

Regardless of the competitive ability of Norway spruce under increasing disturbance regimes, a decrease in wood quality can be expected for this species in the years to come (e.g. wood density). Being the most relevant timber for softwood products in Central and Northern Europe, Norway spruce calls for new silvicultural strategies addressing climate change issues, which include the right choice of provenances and degree of stand density regulation.

\subsubsection{Stress Events and Low-Growth Years}

Many studies use the long-term course of the annual stem diameter growth of trees for analysing low-growth years caused by stress events such as drought, late frost or insect injury (Schweingruber 2012). The studies are often based on dominant trees, in order to keep the effects of competition by neighbours as small as possible (Pretzsch et al. 2020a). The normal level of the sampled individuals is assumed as standard for comparison, and any slump of growth in low-growth years is quantified by the ratio between the reduced and normal level. This results in information about relative growth losses. Zang et al. (2011) revealed, by this method, that the ranking between primary tree species in Central Europe regarding growth losses is Norway spruce, silver fir, Douglas fir, European beech, Scots pine and sessile oak. By comparing the growth reactions in the given years in monospecific stands with neighbouring mixed-species ones, Pretzsch et al. (2013), Grossiord et al. (2014), Thurm et al. (2016) and Ammer (2019) could show that, in some cases, interspecific neighbourhood can reduce species-specific drought stress effects.

Drought events in Central Europe, among others, in 1976, 2003 and 2015, triggered many studies about the effects of episodic drought on the growth and mortality of forest tree species (Ciais et al. 2005; Bréda et al. 2006; Allen et al. 2015). These findings suggest that tree species especially growing at or beyond the border of their natural range, such as Norway spruce or European larch (Larix decidua Mill.) in Central Europe, can show severe growth losses and mortality (Kölling et al. 2009; Lévesque et al. 2013). Scots pine (Pinus sylvestris L.) and sessile oak (Quercus petraea L.) often serve as examples for rather drought-tolerant species (Walentowski et al. 2007; Zang et al. 2011, 2012), more suitable for forestry in Central Europe under climate change towards warm and dry conditions. In order to mitigate drought, 
silviculture aims at the selection of well acclimated species and provenances (Atzmon et al. 2004; Arend et al. 2011; Zang et al. 2011), at reducing stand density (D'Amato et al. 2013; Sohn et al. 2016; Bottero et al. 2017), at modifying the kind of thinning (Rodríguez-Calcerrada et al. 2011; Gebhardt et al. 2014; Pretzsch et al. 2018) or at favouring tree species mixing. The latter, however, is not rated effective for drought mitigation in general (Grossiord 2019). Indeed, in forest stands, species diversity is not always positively related to drought resistance. Conte et al. (2018) observed that stem radial growth and isotope-derived intrinsic water-use efficiency were generally higher in pure than in mixed stands of European beech and Scots pine.

Exemplarily, Figure 6.7 shows species-specific stress reactions caused by the drought year 1976 quantified in relation to the mean growth level in the 3-yearperiod 1973-1975 before the drought stress (reference line $=1.0$ ). The study was based on tree ring measurement on cores from increment chronologies from 559 trees of Norway spruce, European beech and sessile oak in South Germany, with half of them sampled in monospecific stands and the other half in mixed stands (Pretzsch et al. 2013).

For quantifying the resistance, recovery and resilience, indices introduced by Lloret et al. (2011) were applied, allowing for retracing the tree's growth reaction on the episodic drought stress in the years 1976 and 2003. The following general reaction patterns, visualised in Figure 6.7, were found. In pure stands, spruce had the lowest resistance but the best recovery. Oak and beech were more resistant but recovered less pronounced and thus were less resilient. In mixture, spruce and oak performed like in pure stands, but beech was significantly more resistant and resilient than in monocultures. Especially when mixed with oak, beech was facilitated. We hypothesise that the revealed water stress release of beech emerges in mixture because of the asynchronous stress reaction pattern of beech and oak and a facilitation of beech by hydraulic lift of water by oak. A potential positive contribution of species

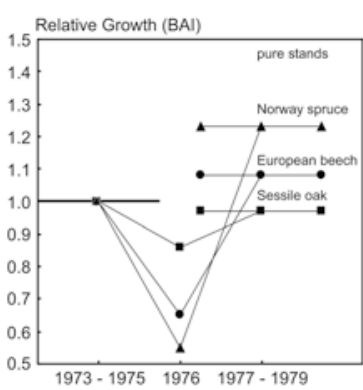

(a)

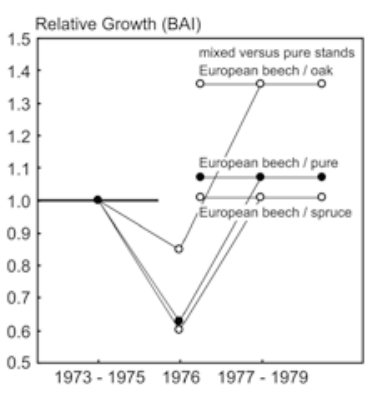

(b)

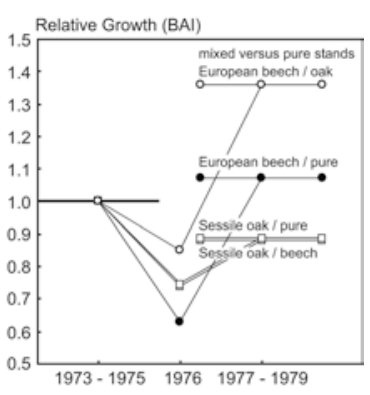

(c)

Fig. 6.7 Species-specific stress reactions caused by the drought year 1976 shown in relation to the mean growth level in the 3-year-period 1973-1975 before the drought stress (reference line $=1.0$ ) (according to Pretzsch et al. 2013). (a) Norway spruce, European beech and sessile oak in pure stands. (b) European beech in pure and mixed stands. (c) European beech and sessile in pure and mixed stands. The courses represent the growth in the dry year 1976 and in the recovery period (periodical mean of 1977-1979) in relationship to the growth in the reference period (periodical mean of 1973-1975) 

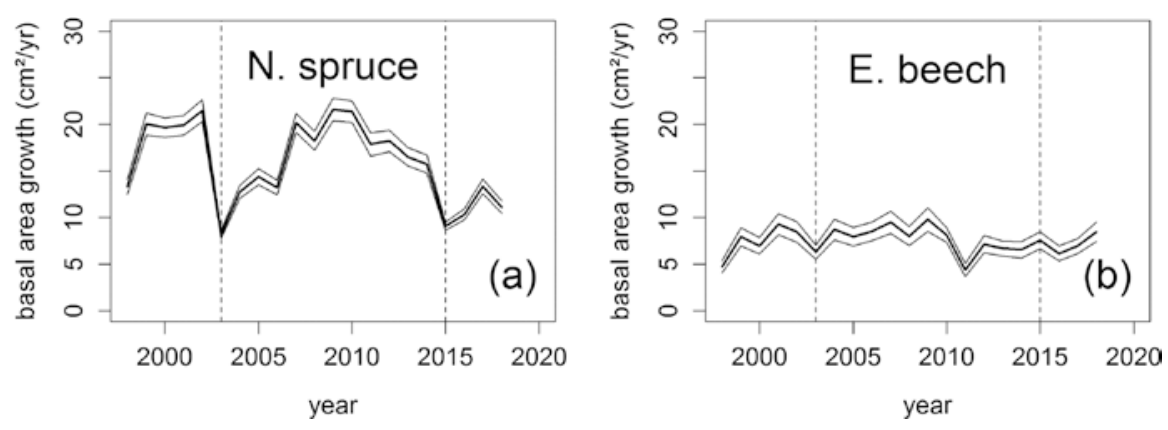

Fig. 6.8 Mean ( \pm SE) annual basal area increment $( \pm$ SE) of all (a) Norway spruce $(n=268)$ and (b) European beech $(n=141)$ from 1998 to 2018. Trees facing rainfall exclusion since 2014 were excluded (tree numbers refer to the year 2003)

with a deep root system (e.g. oak) towards those with shallow roots (e.g. beech) can be hypothesised in mixed forests subjected to drought stress (Zapater et al. 2011).

As another example, we show the growth reactions of Norway spruce and European beech to natural episodic and experimentally extended drought in mature monospecific and mixed-species stands of Norway spruce and European beech in the Kranzberg Forest (Fig. 6.8). From the annual diameter growth records since 1998 based on girth tapes, Norway spruce and European beech both reflect the episodic drought events in 2003 and 2015. The courses of the annual basal area growth ( \pm SE) from 1998 to 2018 is visualised in Figure 6.8. The long-term trend in this period is slightly decreasing for Norway spruce and rather parallel to the X-axis for European beech. This long-term trend, however, is interrupted by slumps of the annual growth in 2003 and 2015, especially in the case of Norway spruce. European beech was much more resistant to the drought years. Norway spruce shows a strong growth reduction in the drought years 2003 and 2015, while European beech shows just a slight growth reduction in 2003 and even an increase in 2015. It is obvious that the growth of Norway spruce is severely reduced by about $50-60 \%$ compared to the growth before the drought period. European beech trees do not exceed half of the growth losses and react much less to drought.

In order to show intra- and inter-species-specific response patterns to drought, we also compared the behaviour in the drought years 2003 and 2015 with the 3-year periods before and after the events (Fig. 6.9). Here, we visualise the results just for 2003, as they were similar concerning the relationships between the species and concerning the intra- and interspecific differences, but more pronounced than in 2015. Figure 6.9a underpins the much stronger effect of drought on the growth of Norway spruce compared with European beech, in general, without considering their intra- and interspecific neighbourhoods.

Interestingly, Norway spruce suffered 10-20\% less under drought when growing in the neighbourhood of European beech (see Fig. 6.9b, mean and SE lines for sb). The growth losses were stronger in the intraspecific neighbourhood of Norway spruce in 2003. The tree growth of the group with intraspecific competition (group 

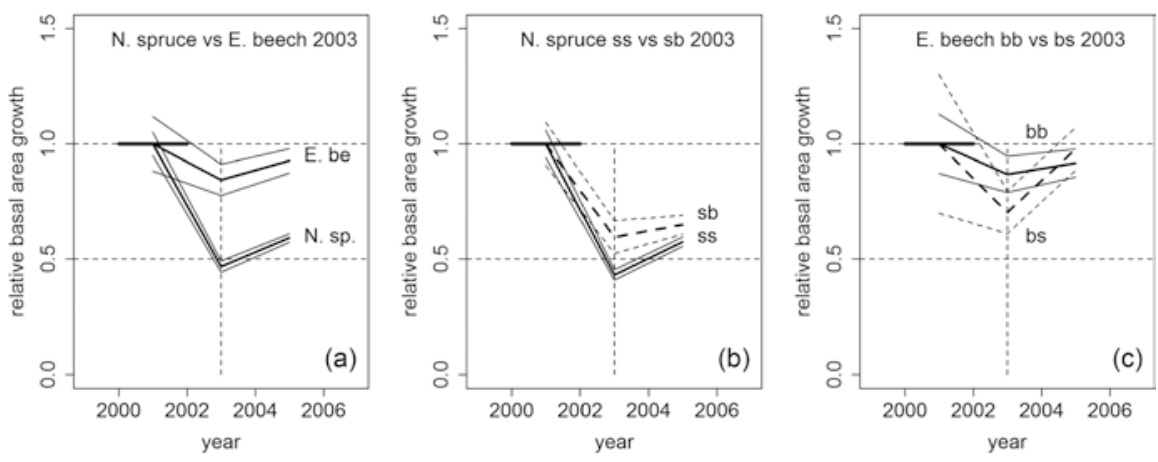

Fig. 6.9 Visualisation of the growth resistance and resilience to the 2003 drought event based on the annual basal area increment $( \pm$ SE) (according to Pretzsch et al. 2020a). The pre-drought growth in the period 2000-2002 is set to 1.0 (1.0 line). The growth in the drought year 2003 and in the post-drought period 2004-2006 was sketched in relation to this reference level. (a) On average, the growth of Norway spruce dropped steeply and recovered slowly; European beech was hardly affected by the 2003 drought. (b) When Norway spruce grew in the interspecific neighbourhood with European beech (sb, broken lines), it was less affected by drought compared with intraspecific constellations (ss). (c) When European beech grew in the interspecific neighbourhood with Norway spruce (bs, broken lines), it was more affected by drought compared with intraspecific constellations (bb)

ss) was significantly lower than the growth in the group with interspecific competition (group sb).

European beech behaved differently (Fig. 6.9c). European beech growth declined significantly stronger under drought in the interspecific neighbourhood but recovered quickly (see Fig. 6.9c, mean and SE lines for bs). In contrast, European beech growing in the neighbourhood of beech trees was much less affected by drought (mean and SE lines for bb). In dry years, Norway spruce seemingly benefits from interspecific neighbourhoods. Similar growth-stabilizing interspecific interactions were reported by del Río et al. (2014).

The results of such studies indicate growth reactions of selected sampled trees. The diagnosis of growth reactions and growth losses at the stand level can show a different picture. Small trees may react differently to stress and partially compensate the growth losses of tall trees in low-growth years (Pretzsch et al. 2018). In addition to the growth of individual trees, stand growth is determined by stand density, mortality and existing natural regeneration that can strongly modify the growth under drought stress (Allen et al. 2015; Pretzsch et al. 2015; Sohn et al. 2016). Stress may also modify height growth, form factor or allometry between root and shoot; all of these aspects are not considered by relative growth analyses based on increment cores of individual trees at breast height (Rötzer et al. 2017).

In summary, the dendrochronological analyses of growth oscillation in drought years may serve as a bioindication and evidence of stress by environmental factors (Dobbertin 2005; Allen et al. 2010), whereas the growth analyses at the stand level provide integrated information of growth reactions that are relevant on ecosystem 
level and for management and planning purposes. Both are useful indicators of climate-smart forestry.

\subsubsection{Vulnerability Related to High Productivity Level}

Compared to the past, forest stand growth has accelerated during the last decades in many areas of Europe (Spiecker et al. 1996; Kauppi et al. 2014; Pretzsch et al. 2014a). Although proceeding on a raised growth level, stands are encountering a series of drought years. But, even if tree and stand growth by this may be reduced below the present level, they still exceed the past level, represented, for instance, by the yield tables. The negative deflection from the currently increased level is naturally interpreted as stress exposure. However, at the same time, the absolute level is still higher than in the past. This may evoke contradictory assessments regarding forest health and vitality.

For showing this concurrency of long-term upward trend and episodic stress events, we present results from an ongoing study of monospecific and mixed-species stands (triplets) of Norway spruce, Scots pine, European beech and sessile oak across Europe (Pretzsch et al. 2020c). Figure 6.10 depicts the stand volume growth of monospecific stands of the respective species in Germany in comparison with the corresponding yield tables by Wiedemann (1943), Jüttner (1955), Assmann and Franz (1963) and Schober (1967).

In the case of Norway spruce (Fig. 6.10a), the observed (oscillating course) and expected growths (unimodal growth curves) were the closest to each other. In the case of European beech (Fig. 6.10b, d), the observed growth strongly deviated from the yield table predictions. Most of the stands showed an increased growth level and an increasing growth trend since one or two decades. Recent drought years just cause an oscillation on a luxury hypertrophy level and only occasionally cause a slump of the growth trajectories below the yield tables used as standard for comparison. Also, Scots pine (Fig. 6.10c, e) strongly exceeded the level of the yield tables and strongly increased in growth. In the last few years, the upward trend is, from time to time, interrupted by low-growth years. The most positive deviations from the yield tables and upward trends were found for the stand growth of sessile oak (Fig. 6.10f); the drought years in 2003 and 2015 had hardly any effects on the annual course of growth of sessile oak. The growth of the mixed-species stands also proceeded above the yield tables and showed an increasing trend (not shown). But, compared with the monospecific stands, the inter-annual oscillation in mixedspecies stands was lower. So, species interactions not only stabilise growth at tree level (Fig. 6.9) but also contribute to greater temporal stability at the stand level (del Rio et al. 2017).

On average, the growth of the analysed stands of spruce, pine, beech and oak was $48 \%$ above the historic level represented by the yield tables (Pretzsch et al. 2020c); this reflects a considerable change of forest growth and potential for wood utilisation compared to the previous century. Growth loss due to drought was highest in 

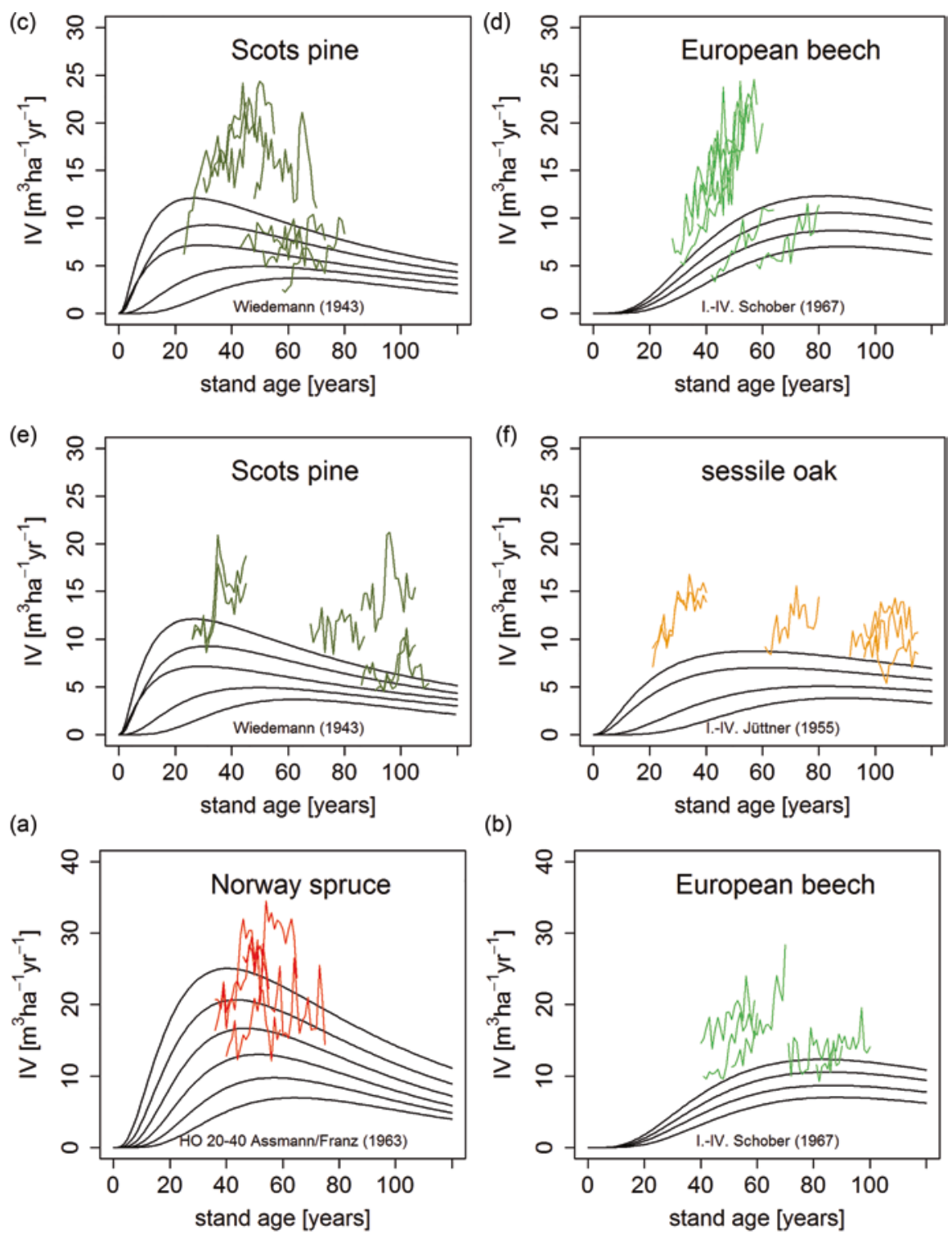

Fig. 6.10 Courses of the absolute annual volume growth (merchantable wood with diameter $7 \mathrm{~cm}$ at the smaller end including bark) of monospecific stands of the triplets of ( $\mathbf{a}$ and $\mathbf{b}$ ) Norway spruce and European beech, (c and d) Scots pine and European beech and (e and f) Scots pine and sessile oak in the period 1997-2018 compared with the courses of the yield tables for moderate thinning by Wiedemann (1943), Jüttner (1955), Assmann and Franz (1963) and Schober (1967) 


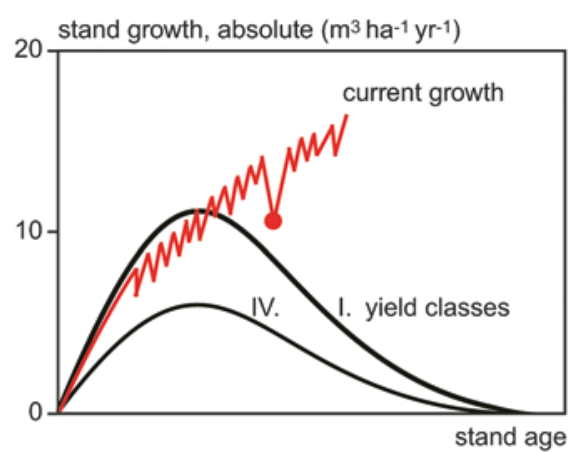

(a)

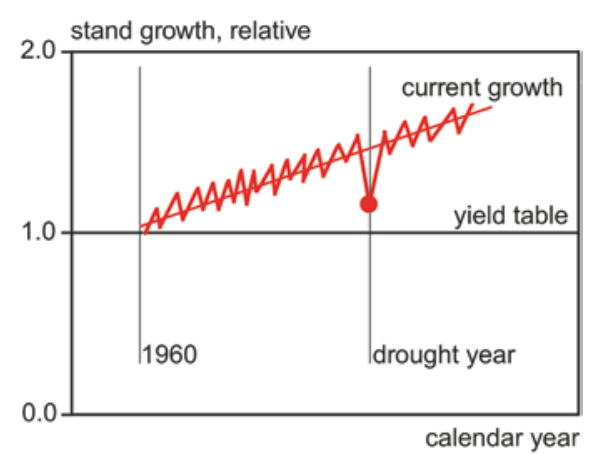

(b)

Fig. 6.11 Growth of traditional yield table vs. current reality in schematic (a) absolute and (b) relative representation. Growth predicted by yield tables (yield classes I and IV), current growth trend and low-growth events caused by drought years (growth decrease marked by filled circle). In the marked drought year, the stand growth would lie under the level of the upward trend but still above the level of the yield tables ( 1.0 line)

Norway spruce stands, lowest in sessile oak stands and medium in European beech and Scots pine stands. Mixed-species stands performed slightly better in drought years but not significantly. The current growth courses of the analysed stands can be understood as a new standard. In the recent drought years, the stand growth was reduced on average by $28 \%$; in the most favoured or unfavoured cases, it was reduced by $19 \%$ and $37 \%$, respectively, referenced at the new standard.

The aggregated picture applying for sites with medium to good growing conditions, i.e. for many sites in the Central European lowlands, is given in Figure 6.11. Figure 6.11a shows the course of growth predicted by the yield tables (curves for yield classes I and IV), the current annual course of growth (sawtooth curve) and the low-growth collapse in a drought year (minimum value marked by a dot) in schematic representation at the absolute scale. Figure $6.11 \mathrm{~b}$ shows the same relationships at a relative scale. Both graphs reveal that the growth in the drought year declines below the level of the current upward growth trend, but it is still above the level of the yield table. This means that the growth is reduced by drought stress but may still lie considerably above the growth predicted by the yield tables.

\subsection{Acclimation, Adaptation and Recovery}

\subsubsection{Acclimation}

Trees and stands may physiologically or morphologically acclimate to drought stress (Cinnirella et al. 2002; Lapenis et al. 2005; Reich et al. 2016). Here, we show an example of trees' acclimation to extended drought stress (Fig. 6.12). In a rainfall exclusion experiment, Goisser et al. (2016) and Pretzsch et al. (2020a) analysed the 

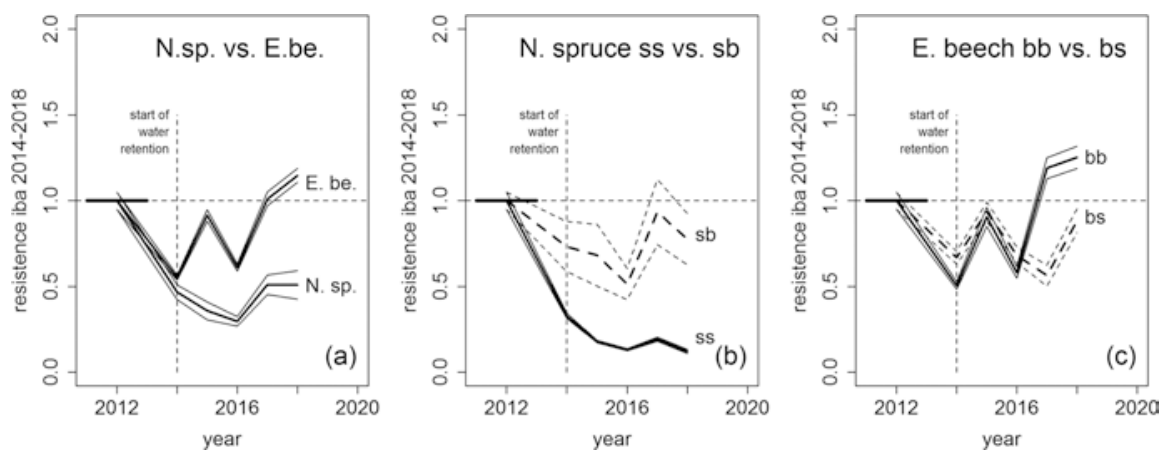

Fig. 6.12 Visualisation of the resistance to the 2014-2018 rainfall exclusion based on the singletree annual basal area increment ( \pm SE). Pre-drought growth in the period 2011-2013 is set to 1.0 (1.0 line, solid black); the growth during years of the rainfall exclusion is related to the pre-drought level. (a) On average, growth of Norway spruce dropped steeply and recovered slowly; growth of European beech dropped less and even increased above the level of the pre-drought period after 4 years. (b) When Norway spruce grew in the interspecific neighbourhood with European beech (sb, broken lines), it was less affected (20-30\%) during the rainfall exclusion in the first years and recovered remarkably compared with spruce trees in intraspecific constellations (ss). (c) When European beech grew in the interspecific neighbourhood with Norway spruce (bs, broken lines), it performed better in the first years of drought but then relapsed the growth of beech trees in intraspecific neighbourhoods (bb)

courses of the annual basal area increments within a 5-year period of water exclusion over all summer periods. Figure 6.12a shows the behaviour of Norway spruce and European beech in monospecific and mixed stands. Both species strongly reduced their growth in the first year after the rainfall exclusion. Norway spruce continued to decrease but stabilised in 2016-2018. European beech stabilised even earlier and rearrived at the base level in 2018. Since 2015, Norway spruce grew on average significantly less than European beech on the treatment plots. This underpins the species-specific drought tolerance reviewed by Niinemets and Valladares (2006). The asymptotic growth trend of Norway spruce and the upward growth trend of European beech after multi-year drought can be interpreted as acclimation.

Especially in the case of Norway spruce, the neighbourhood seems to matter for the growth behaviour imposed by experimentally extended drought stress (Fig. 6.12b). Norway spruce growing in the neighbourhood of spruce trees displayed a much stronger growth decrease than those in vicinity to European beech. In the case of European beech, both trees in inter- and intraspecific neighbourhood behave similarly in the first 3 years (Fig. 6.13c). Since 2016, we found significant differences between the two groups, i.e. beech trees in intraspecific competition outgrew those neighboured by spruce trees.

In summary, the experimentally induced drought from 2014 to 2018 caused a strong growth reduction in the first year, followed by a slight acclimation to the dry conditions. European beech acclimatised and recovered better than Norway spruce; Norway spruce acclimatised better in the neighbourhood of beech trees. For Norway 
spruce tree mortality was fivefold, while for European beech it is similar to the longterm mortality rate on the untreated plots.

\subsubsection{Adaptation}

The intraspecific genotypic and phenotypic variability plays an important role in terms of adaptation. Figure 6.13a illustrates how a high genetic diversity can contribute to adaptation, as each genotype shows a distinct optimum curve to climate conditions.

Similarly, there can be substantial differences in expression of the optimum curve among different provenances of a species (Benito Garzón et al. 2011) through adaptation to varying climate conditions (Aitken et al. 2008).

The Scots pine provenance trial Schwabach 304, established in 1927, provides an example for provenance-dependent behaviour of growth (Fig. 6.14a). This experiment revealed that the production of the provenance "Bamberg" was inferior until an age of 50 years compared to the provenances "Schwabach" and "Unterfranken". The provenance Bamberg seems to be better suitable for the changing growing conditions since the last century. However, it turned to the most productive provenance, possibly indicating higher adaptation to the specific site conditions. In the case of the Douglas fir provenance trial Kösching 95 (established in 1961, first survey 1961, last survey 2015), all provenances performed very similarly during the juvenile stand development. With increasing age, however, the difference in total stand growth between the weakest and strongest performing provenance becomes a remarkable $500 \mathrm{~m}^{3} \mathrm{ha}^{-1}$ (Fig. 6.14b). This trial also includes plots of Norway spruce,

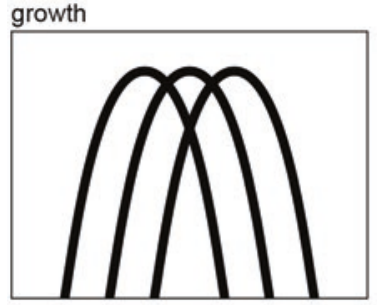

(a) growth

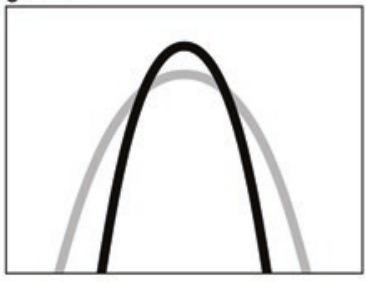

(b)

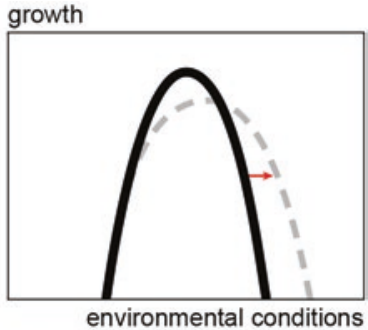

(c)

Fig. 6.13 Growth of different genotypes depending on their real ecological niche in schematic representation (niche reduced to one axis for simplifying the representation). (a) Unimodal relationship between site conditions for different genotypes. A greater genetic diversity can contribute to a better adaptation to climate change. (b) Growth of two species with different phenotypic plasticity. A higher phenotypic plasticity can reduce the impact of climate change and favour "adaptation" in a broad sense of the term. (c) Shift in species growth response along the ecological niche caused by epigenetic preconditions. Different growth responses to environmental conditions by epigenetic changes can be inherited in the new generation and contribute to tree species adaptation 

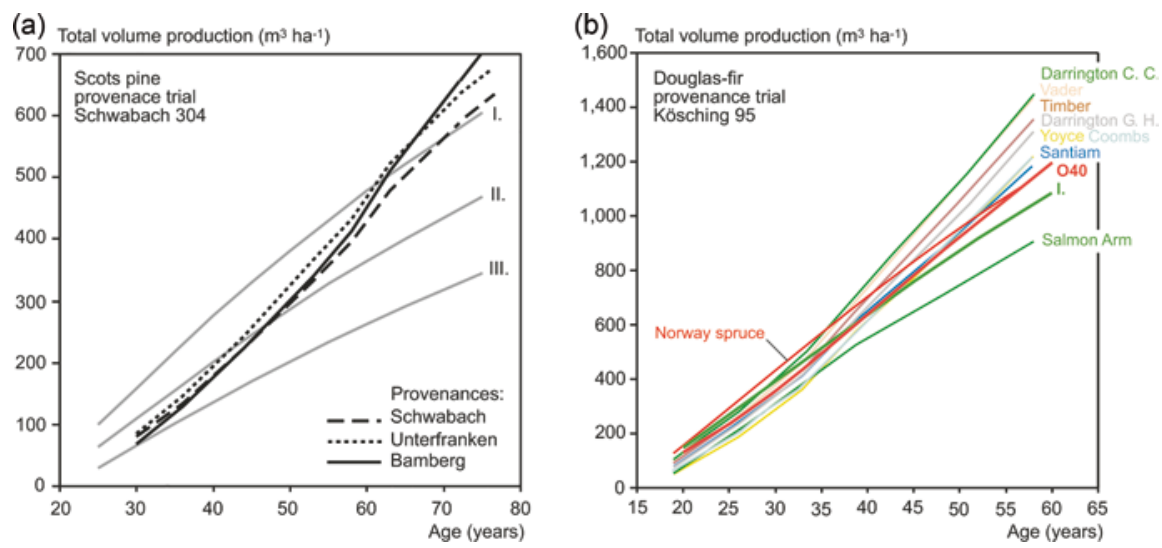

Fig. 6.14 Long-term observations can reveal changes in the performance ranking of different species' provenances as well as deviations of their growth and yield characteristics from the prediction by yield tables. (a) On the Scots pine provenance trial Schwabach 304, initially low-performing provenances finally have superior total production. After 20 years, all the three provenances surpass the level of the yield table. (b) Douglas fir provenance trial Kösching 95, where some Douglas fir provenances significantly excel the other and the total production of the Norway spruce reference plots in advanced age. The yield tables for Scots pine by Wiedemann (1943, yield classes IIII) and for Douglas fir by Bergel (1985, yield class I) and Norway spruce by Assmann and Franz (1963, O 40) were used as reference

which performs similarly to Douglas fir initially but lags behind most of the Douglas fir provenances at advanced ages. The deviations from the reference yield tables are negligible in the beginning but accumulate strongly with increasing stand age.

The long-term changes in ranking and trend, depicted in Figure 6.14, underpin that the choice of silvicultural options (e.g. provenance, thinning and tree species) should not be based just on early tests but on long-term observation. Real-time series of observations cannot simply be replaced by artificial time series, which try to derive the development over age by measuring and combining stands of different ages on the same site.

Generally, a higher genetic diversity implies more possibilities of adaptation to changing conditions, but species adaptation through selection during the regeneration phase is a long-lasting process. Therefore, other aspects, such as species phenotypic plasticity to environmental conditions or the above-mentioned ability of acclimation, are important for adaptation to climate change, in a broader perception of the term "adaptation". More plastic species or provenances are expected to resist better to climate changes in large parts of their distribution areas (Fig. 6.13b). However, plasticity is not always linked to genetic diversity (Mutke et al. 2010); therefore, it does not always guarantee good performance.

Epigenetic changes can also have important effects on species adaptability (Fig. 6.13c). Current research scrutinises to what extent climate change can cause heritable epigenetic changes and adaptation of trees beyond the genetic adaptation by sexual reproduction (Franks Hoffmann 2012; Verhoeven et al. 2016). That 
environmentally induced epigenetic changes may be inherited by future generations is of special relevance for long-lived organisms, such as trees (Bräutigam et al. 2013). Rico et al. (2014) and Shanker et al. (2014) report on epigenetic changes under drought stress, and Bossdorf et al. (2008) discussed how to consider such high important aspects in future experiments in ecology.

\subsubsection{Recovery}

The recovery capacity after cessation of disturbance is an important characteristic of tree growth to better understand growth reaction patterns under changing environment. Beyond the already revised growth response to extreme annual events through the analysis of resistance, recovery and resilience indices by Lloret et al. (2011), here, we present two examples of growth response to longer disturbances, such as $\mathrm{SO}_{2}$ pollution and $\mathrm{O}_{3}$ exposure, and the recovery afterwards.

Growth Reactions of Norway Spruce and Silver Fir to $\mathrm{SO}_{2}$ Pollutants The stem diameter growth trajectories of Norway spruce and silver fir in Fig. 6.15 show the stress reaction and recovery caused by $\mathrm{SO}_{2}$ pollutants (1950-1985) and dry years $(1976,2003)$. The trajectories are based on 118 trees per species sampled by increment boring in 22 mixed-species stands across Germany. The stands cover a wide

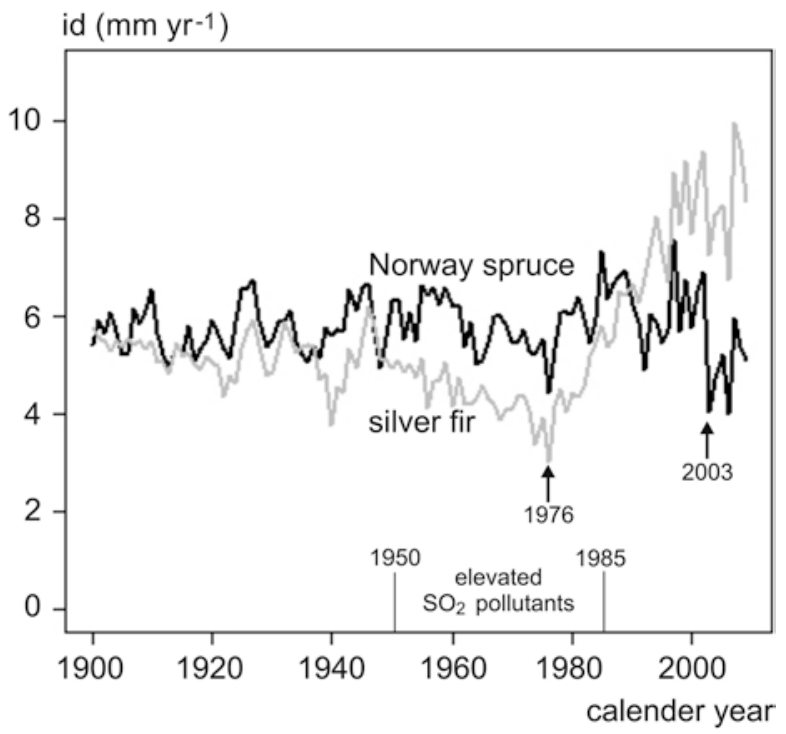

Fig. 6.15 Average course of the stem diameter increment (id $\mathrm{mm} \mathrm{yr}^{-1}$ ) of about 100 -year-old silver fir $(n=118)$ and Norway spruce $(n=118)$, in Bavaria and Lower Saxony. The graph shows the period 1950-1985 with increased $\mathrm{SO}_{2}$ pollution, the species-specific growth trend after 1985 with reduced $\mathrm{SO}_{2}$ pollution and the drought years 1976 and 2003 (Uhl et al. 2013) 
range of site conditions, within and beyond the natural distribution of both species, in Bavaria and Lower Saxony. In Bavaria, the tree age of Norway spruce and silver fir was 110 and 114 years, respectively, and in Lower Saxony it was 72 and 88 years, respectively. Since 1900, both species first show a rather similar and steady level of growth. Silver fir then shows a growth depression from 1950 to 1980 and a growth recovery afterwards. The growth of Norway spruce is superior to silver fir in the period 1950-1980 and turns to be inferior after 1980 .

The growth of silver fir was strongly reduced by the high $\mathrm{SO}_{2}$ pollutants in the period 1950-1980 (Uhl et al. 2013). After reduction of the $\mathrm{SO}_{2}$ load in the atmosphere by installation of filters in power stations (Joos 2006; Elling et al. 2009), the stem diameter growth of silver fir increased continuously in the last 20-30 years despite the advancing age. The finding that the growth of silver fir dropped less and recovered faster than the growth of Norway spruce in drought years means that the vitality changed in favour of silver fir in the last decades. Consequently, in the very widespread mixed-species stands of Norway spruce, silver fir and European beech in European mountain regions, silver fir gained in competitive strength and productivity compared to the other species (Pretzsch et al. 2015; Bosela et al. 2018; Hilmers et al. 2019).

Growth Reactions to Chronic $\mathrm{O}_{3}$ Stress and Recovery After Temporal $\mathrm{O}_{3}$ Exposure Increased $\mathrm{O}_{3}$ concentration in the air can have significantly detrimental effects on the health and growth of trees in urban areas and forests (Matyssek und Sandermann 2003). $\mathrm{O}_{3}$ fumigation experiments show that ozone exposure can reduce the photosynthesis (Botkin et al. 1972; Karnosky et al. 2007; Wittig et al. 2009), the carbon assimilation (Chappelka and Samuelson 1998; Sitch et al. 2007), the growth (Wipfler et al. 2005; Pretzsch und Schütze 2018) and allometry of trees (Dickson et al. 2001; Grantz et al. 2006; Pretzsch et al. 2010). The effect of $\mathrm{O}_{3}$ on growth can be analysed by tree ring analyses and comparison of exposed trees with controls (Pretzsch und Schütze 2018).

The free-air ozone fumigation experiment in the Kranzberg Forest showed how 80-year-old Norway spruce and European beech trees reacted to double-ambient $\mathrm{O}_{3}$ exposure (2000-2007) and also how they behaved after the stop of the temporary exposure (Matyssek et al. 2010; Häberle et al. 2012). During the phase with doubleambient $\mathrm{O}_{3}$ exposure $\left(2 \times \mathrm{O}_{3}\right)$, the annual basal area increments of Norway spruce and European beech decreased by $24 \%$ and $32 \%$, respectively (Fig. 6.16). In the period 2008-2016, after the stop of the exposure, both species recovered. The basal area increments of the previously $\mathrm{O}_{3}$-fumigated trees recovered and raised by $14 \%$ and $24 \%$ above the level of the control trees $\left(1 \times \mathrm{O}_{3}\right)$. So, they nearly caught up with the control trees regarding diameter growth. However, the resistance and resilience of the previously fumigated trees to drought and late frost were lower compared with the control trees. This underlines that measures for pollution control may result in a quick recovery from chronic $\mathrm{O}_{3}$ stress and emphasises the relevance of $\mathrm{O}_{3}$ control for the health and the carbon sink function of trees and forests (Matyssek et al. 2010). 
Tree diameter increment

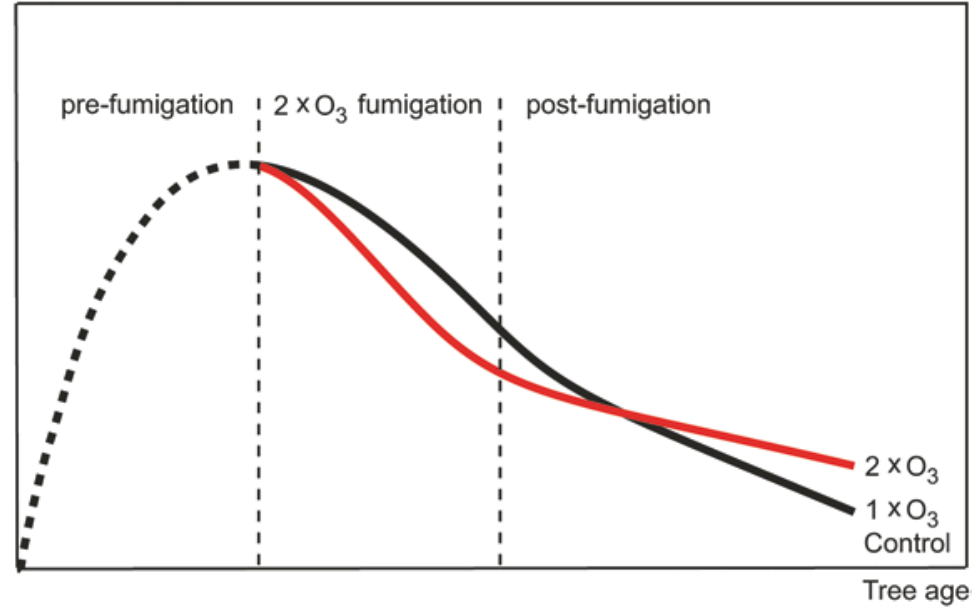

Fig. 6.16 Pattern of growth responses of mature Norway spruce and European beech to temporary $2 \times \mathrm{O}_{3}$ ozone fumigation, according to Pretzsch et al. (2018). Free-air twice-ambient ozone fumigation $\left(2 \times \mathrm{O}_{3}\right)$ reduced diameter increment of mature Norway spruce and European beech within the $2 \times \mathrm{O}_{3}$ fumigation period from 2000 to 2007. In the post-fumigation period, growth of the former fumigated trees can recover and even exceed the growth of the control trees. $1 \times \mathrm{O}_{3}$ means ambient ozone concentration and represents the control tree (black line); $2 \times \mathrm{O}_{3}$ means twiceambient ozone-fumigated trees (red line)

\subsection{Discussion: Implications for Environmental Monitoring, Forest Ecology and Management}

The reviewed tree and stand growth behaviour by reasons of changing environments is highly relevant as any change of forest growth and structure has strong impacts on the provision of ecosystem goods and services. In the following, we discuss the implications for environmental monitoring, forest ecology and management.

\subsubsection{Environmental Monitoring}

As tree and stand growth strongly depends on environmental conditions, their observation delivers a unique contribution to environmental monitoring. Thus, the tree and stand growth measured on long-term experiments and the tree growth rates retrospectively derived from increment cores and stem discs can provide evidence of environmental changes (Schweingruber 2012). Growth records from trees or stands without active forest management are of special value, as their growth courses are not superimposed by silvicultural management effects. Long-term observation helps to quantify the human footprint on nature (Pretzsch et al. 2014a). 
In temperate Europe, there is a patchwork of forests with positive, neutral and negative growth reactions to the ongoing change of environmental conditions. In regions with sufficient water supply, growth strongly accelerated due to favourable effects of global change, such as nitrogen deposition, extension of the growing season (McMahon et al. 2010) and rise of the $\mathrm{CO}_{2}$ concentration (Ewald et al. 2004). In drier regions, forest growth is reduced by drought and accompanied biotic calamities (Martin-StPaul et al. 2013). In fact, many forests show growth slumps in dry years but are currently growing at higher levels than before, requiring a long-term reference for impact assessment (Fig. 6.11).

The demonstration of forest growth and decline and the practical consequences on long-term experiments can motivate measures for environmental care and pollution control (Matyssek and Sandermann 2003; Uhl et al. 2013). The growth trends and events on environmental conditions can also be used for assessing the climate smartness of various forest and stand types and contribute to developing indicators of stability and climate smartness for monitoring and decision-making purposes (Bowditch et al. 2020; Santopuoli et al. 2021).

\subsubsection{Forest Ecology}

The accelerated tree growth and forest aging and the projected sink saturation require conformance of all associated organisms, including humans. Plants and animals inhabiting these habitats depend on specific phases in stand development and structure; faster growth means interference in species living conditions and demands for higher mobility. In other areas, growth decline may call in question the future of tree species and the associated plants and animals. In the lowlands, we find horizontal mosaics and, in the mountains, elevation zones with changing growth, changing competitive strength of the species and a transition to species with ecological niches better suitable for both the continuously and abruptly changing growth conditions.

If we interpret tree growth trends as an indication of fitness (Dobbertin 2005), we may consider that some species, such as Norway spruce and Scots pine, especially when cultivated beyond their natural range in dry lowland areas, lose competitiveness. In many cases their growth is still on a rather high level but with a decreasing tendency, especially caused by drought years that became more frequent in the last decades.

Long-term observation of tree growth shows that trees can recover from episodic and chronic stress and that they are also able to acclimatise to a certain degree to, e.g. drought stress (Pretzsch et al. 2020a). Future research will show the potential of acclimatisation and of adaptation over successive generations. Natural regeneration may pave the way to a continuous adaptation by natural selection of the fittest. Permanent plots surveyed with a combination of high resolution and coarse size will be required to track forest demography in time and space (e.g. tree mortality, age structure) and understand scale and pattern of forest development (e.g. species diversity, vegetation shift). 
The shown growth trends suggest new experiments in monospecific and mixedspecies stands, in order to better understand the effects of environmental changes on forest resilience. Of importance are, e.g. experiments analysing the provenance selection and adaptation to climate change, the impacts of tree species mixing on growth stability, the potential for acclimation and adaptation of tree species, the effects of various silvicultural measures (e.g. thinning), the interactive consequences of disturbances and the effects of nutrient addition on stress resistance, resilience and recovery.

\subsubsection{Forest Management}

Management options and decisions regarding the choice of species and provenance, stand regeneration, spacing, thinning and rotation length depend on information about the current tree and stand growth. Susceptibility of presently used species to biotic or abiotic damages will determine the selection of new provenances and foreign species (Atzmon et al. 2004; Arend et al. 2011; Zang et al. 2011). By early stand regeneration and transition to natural regeneration, the stand acclimation and adaptation to drought may be promoted (Aasamaa et al. 2004). Spacing and thinning may be intensified in order to use the accelerated growth or to reduce stand density and drought stress (Sohn et al. 2016). Long-term experiments show, in many regions, an increase of the maximum stand density; this means that keeping stands at the traditional density levels may cause severe growth losses as the optimal density will be under matched. The accelerated growth may suggest a shortening of the rotation period (Pretzsch et al. 2014a).

All these measures depend on information about growth trends and short-term growth reactions to adjust forest management and maintain sustainability, in particular, under changing environmental conditions. More rapid tree growth can result in earlier harvest threshold diameters and rotation due to increased stand productivity, which can raise the annual harvest. Recent growth trends allow foresters to maintain much higher growing stocks. However, strong thinning, which uses past conditions as a guideline, might reduce stand density, such that the actual growth potential is not fully realised. In addition, a shortened rotation period can mean reduced risk in terms of forest damage, including windthrow, bark beetle infestation and/or snow breakage. On the other hand, at sites with decreasing growth trends and decay symptoms, urgent adaptation strategies are required, such as species diversification, density regulation, promotion of natural regeneration or even, in some cases, species or provenance assisted migration.

For a specific stand mean tree size, standing stock and mortality rate can be achieved one or more decades earlier. This leaves age-based experience values, widely used yield tables and other models and many traditional management guidelines to become obsolete. Trade-offs exist between shortening rotation period to maximise carbon sequestration and lengthening tree growth to reduce biodiversity loss. Growth records may further serve for updating forest growth models not only 
for monocultures but also for more complex mixed-species stands. Such models should provide forest management with appropriate growth and yield information for calculation of the annual sustainable harvest. The underlying experimental and observation plots may serve as demonstration and training plots on how to manage forest under environmental changes and as silvicultural assistance to the transition from high-risk monocultures to close-to-nature forest systems, towards climatesmart forestry.

\subsection{The Importance of Long-Term Experiments for Fact-Finding}

As most of the results presented in this chapter are based on long-term growth and yield experimental plots, we finally discuss the importance of long-term experiments for fact-finding. The founding fathers of forest yield science, such as Danckelmann and Schwappach, were convinced that trees and forests require longterm observation, and for this purpose they established the first forest research stations, beginning in 1870 (Ganghofer 1881; Milnik 1999; Landesforstanstalt Eberswalde 2001). Most of our scientific knowledge of tree and stand dynamics, and practical decision, is based on long-term experiments. However, long-term experiments are often under scrutiny, endangered and sacrificed for cost reduction. The reasons are as follows: forest areas with long-term experiments have to be left out from regular forest operations, long-term experiments are costly and waiting for some results more than a couple of years hardly fits into these fast-moving times.

A misleading argument for discontinuance is that forest inventories established in the last decades at national or enterprise level render long-term experiments superfluous. Long-term experiments and temporary plots are rather complementary, more than redundant (Nagel et al. 2012). Long-term experiments provide farbackward-reaching time series of growth and yield for selected sites; they also include extreme variants, such as unthinned stands or solitary growing conditions, which are hardly represented by inventories. Unthinned plots can be important as reference (maximum density, site-specific productivity), and solitary plots are relevant for understanding tree behaviour (aging, wood quality) under strong thinning and the trade-off between tree and stand level performance. Temporary plots and forest inventories, in contrast, include mainly routinely managed stands (mean stand density, common silvicultural treatment) and provide a representative overview of the current growth behaviour.

Forest inventories can provide large-scale representative data, and the information potential can be exploited by big data methods (e.g. Liang et al. 2016). However, inventories may hardly provide information about the stand history and intermediate yield; a lack that can be partly remedied by permanent inventory plots, when they get measured repeatedly and gradually, provide longer time series. Long-term experiments, in contrast, can reveal the cause-effect relationship of various 
treatment options on tree and stand behaviour, as they are established under controlled continuous (ceteris paribus) conditions. Inventory plots indicate correlations but provide no evidence for casualties, as they can vary in many traits beyond the factor in question. Long-term experiments strive for general rules, laws and understanding, while inventory plots aim at regional information for practical purposes. Simulation models can make use of both long-term plots for developing the thinning, mortality and regeneration algorithms and inventory data for calibration of the site-growth relationship, model initialisation and risk assessment.

Large-scale and long-term monitoring plots may be useful to characterise ecological processes (succession, outbreak, windthrow, etc.), thus providing models with data from heterogeneous conditions and including temporal variability of climate. Monitoring of large plots helps to emerge the effect of processes that are spatially autocorrelated (dispersal, competition, facilitation or mortality). Monitoring of permanent plots helps intercept the impact of phenomena that are temporally discrete (e.g. extreme events). During the careers of research topics, such as impact of acid rain, nitrogen deposition or climate change or global change on forests, repeated observation on permanently marked plots provided information far beyond the purpose they originally were established for. They represent stands with known history regarding establishment, silvicultural treatment and disturbances. They offer time series of stand development for biomonitoring, development of silvicultural treatment, modelling and demonstration and training.

Current course of growth may reveal site- and species-specific reaction to various disturbances and may contribute to a less emotional but more objectified discussion of the human influence on tree growth and forest dynamics. While the public debate about forest ecology and health changes its focus typically minute by minute, long-term experiments provide a differentiated and consolidated information base about where and to what extent not only forest growth is influenced by humans but also that pollution and climate control can help.

Acknowledgements The authors would like to acknowledge networking support by the COST (European Cooperation in Science and Technology) Action CLIMO (Climate-Smart Forestry in Mountain Regions - CA15226), which received funding under the EU Framework Programme for Research and Innovation HORIZON 2020.

The first author wishes to thank the German Science Foundation (Deutsche Forschungsgesellschaft) for funding the projects "Structure and dynamics of mixed-species stands of Scots pine and European beech compared with monospecific stands. Analysis along an ecological gradient through Europe" (\# DFG PR 292/15-1) and "From near-death back to life: Mixed stands of spruce and beech under drought stress and stress recovery. From pattern to process" (\# DFG PR 292/22-1). We would also like to thank the Bavarian State Ministry for Environment and Consumer Protection for funding the project "Pine (Pinus sylvestris) and beech (Fagus sylvatica) in mixed stands: Suitable partners to ensure productivity on dry sites in times of climate change (KROOF II)" (\# GZ: TKP01KPB-73853) and the Bavarian State Ministry for Nutrition, Agriculture and Forestry for funding the project "W047" (\# GZ: 7831-28160-2018). We further thank the 
Bayerische Staatsforsten (BaySF) for supporting the establishment of the plots and the Bavarian State Ministry for Nutrition, Agriculture and Forestry for permanent support of the project W007 "Long-term experimental plots for forest growth and yield research" (\# 7831-26625-2020). Thanks to all the project partners of the mentioned projects for providing data on tree and stand growth across Europe. Thanks also goes to anonymous reviewers for their constructive criticism.

\section{References}

Aasamaa K, Sõber A, Hartung W, Niinemets Ü (2004) Drought acclimation of two deciduous tree species of different layers in a temperate forest canopy. Trees 18(1):93-101

Aitken SN, Yeaman S, Holliday JA et al (2008) Adaptation, migration or extirpation: climate change outcomes for tree populations. Evol Appl 1(1):95-111

Allen CD, Macalady AK, Chenchouni H et al (2010) A global overview of drought and heatinduced tree mortality reveals emerging climate change risks for forests. For Ecol Manag 259(4):660-684

Allen CD, Breshears DD, McDowell NG (2015) On underestimation of global vulnerability to tree mortality and forest die-off from hotter drought in the Anthropocene. Ecosphere 6(8):1-55

Ammer C (2019) Diversity and forest productivity in a changing climate. New Phytol 221(1):50-66

Arend M, Kuster T, Günthardt-Goerg MS, Dobbertin M (2011) Provenance-specific growth responses to drought and air warming in three European oak species (Quercus robur, Q. petraea and $Q$. pubescens). Tree Physiol 31(3):287-297

Assmann E, Franz F (1963) Vorläufige Fichten-Ertragstafel für Bayern. Forstl Forschungsanst München, Inst Ertragskd, München, 104 p

Atzmon N, Moshe Y, Schiller G (2004) Eco-physiological response to severe drought in Pinus halepensis Mill. trees of two provenances. Plant Ecol 171(1-2):15-22

Bauhus J, Forrester DI, Gardiner B et al (2017) Ecological stability of mixed-species forests. In: Mixed-species forests. Springer, Berlin, Heidelberg, pp 337-382

Bebi P, Kienast F, Schönenberger W (2001) Assessing structures in mountain forests as a basis for investigating the forests' dynamics and protective function. For Ecol Manag 145(1/2):3-14

Benito Garzón M, Alía R, Robson TM et al (2011) Intra-specific variability and plasticity influence potential tree species distributions under climate change. Glob Ecol Biogeogr 20:766-778

Bergel D (1985) Douglasien-Ertragstafel für Nordwestdeutschland. Niedersächs Forstl Versuchsanst, Abt Waldwachstum, Göttingen, p 72

Bontemps JD, Hervé JC, Duplat P et al (2012) Shifts in the height-related competitiveness of tree species following recent climate warming and implications for tree community composition: the case of common beech and sessile oak as predominant broadleaved species in Europe. Oikos 121:1287-1299

Bosela M, Lukac M, Castagneri D et al (2018) Contrasting effects of environmental change on the radial growth of co-occurring beech and fir trees across Europe. Sci Total Environ 615:1460-1469

Bossdorf O, Richards CL, Pigliucci M (2008) Epigenetics for ecologists. Ecol Lett 11(2):106-115

Botkin DB, Janak JF, Wallis JR (1972) Some ecological consequences of a computer model of forest growth. J Ecol 60:849-872

Bottero A, D'Amato AW, Palik BJ et al (2017) Density-dependent vulnerability of forest ecosystems to drought. J Appl Ecol 54(6):1605-1614

Bowditch E, Santopuoli G, Binder F et al (2020) What is Climate Smart Forestry? A definition from a multinational collaborative process focused on mountain regions of Europe. Ecosyst Serv 43:101113. https://doi.org/10.10/j.ecoser.2020.101113

Bräutigam K, Vining KJ, Lafon-Placette C et al (2013) Epigenetic regulation of adaptive responses of forest tree species to the environment. Ecol Evol 3(2):399-415 
Bréda N, Huc R, Granier A et al (2006) Temperate forest trees and stands under severe drought: a review of eco-physiological responses, adaptation processes and long-term consequences. Ann For Sci 63(6):625-644

Chappelka AH, Samuelson LJ (1998) Ambient ozone effects on forest trees of the eastern United States: a review. New Phytol 139(1):91-108

Ciais P, Reichstein M, Viovy N et al (2005) Europe-wide reduction in primary productivity caused by the heat and drought in 2003. Nature 437(7058):529

Cinnirella S, Magnani F, Saracino A et al (2002) Response of a mature Pinus laricio plantation to a three-year restriction of water supply: structural and functional acclimation to drought. Tree Physiol 22(1):21-30

Conte E, Lombardi F, Battipaglia G et al (2018) Growth dynamics, climate sensitivity and water use efficiency in pure $v s$. mixed pine and beech stands in Trentino (Italy). For Ecol Manag 409:707-718

D'Amato AW, Bradford JB, Fraver S et al (2013) Effects of thinning on drought vulnerability and climate response in north temperate forest ecosystems. Ecol Appl 23(8):1735-1742

del Río M, Schütze G, Pretzsch H (2014) Temporal variation of competition and facilitation in mixed species forests in Central Europe. Plant Biol 16(1):166-176

del Rio M, Pretzsch H, Ruiz-Peinado R et al (2017) Species interactions increase the temporal stability of community productivity in Pinus sylvestris-Fagus sylvatica mixtures across Europe. J Ecol 105(4):1032-1043

del Río M, Vergarechea M, Hilmers T et al (2020) Effects of elevation-dependent climate warming on intra- and inter-specific growth synchrony in mixed mountain forests. For Ecol Manag 479:10. https://doi.org/10.1016/j.foreco.2020.118587

Dickson RE, Coleman MD, Pechter P et al (2001) Growth and crown architecture of two aspen genotypes exposed to interacting ozone and carbon dioxide. Environ Pollut 115(3):319-334

Dobbertin M (2005) Tree growth as indicator of tree vitality and of tree reaction to environmental stress: a review. Eur J For Res 124(4):319-333

Elling W, Dittmar C, Pfaffelmoser K et al (2009) Dendroecological assessment of the complex causes of decline and recovery of the growth of silver fir (Abies alba Mill.) in southern Germany. For Ecol Manag 257(4):1175-1187

Ewald J, Felbermeier B, von Gilsa H et al (2004) Zur Zukunft der Buche (Fagus sylvatica L.) in Mitteleuropa. Eur J For Res 123:45-51

Franks SJ, Hoffmann AA (2012) Genetics of climate change adaptation. Annu Rev Genet 46:185-208

Ganghofer von A (1881) Das Forstliche Versuchswesen, Band I. Augsburg, 1881, p 505

Gebhardt T, Häberle KH, Matyssek R et al (2014) The more, the better? Water relations of Norway spruce stands after progressive thinning. Agric For Meteoral 197:235-243

Gimmi U, Poulter B, Wolf A, Portner H et al (2013) Soil carbon pools in Swiss forests show legacy effects from historic forest litter raking. Landsc Ecol 28(5):835-846

Goisser M, Geppert U, Rötzer T et al (2016) Does belowground interaction with Fagus sylvatica increase drought susceptibility of photosynthesis and stem growth in Picea abies? For Ecol Manag 375:268-278

Grantz DA, Gunn S, Vu HB (2006) O3 impacts on plant development: a meta-analysis of root/ shoot allocation and growth. Plant Cell Environ 29(7):1193-1209

Grossiord C (2019) Having the right neighbors: how tree species diversity modulates drought impacts on forests. New Phytol. https://doi.org/10.1111/nph.15667

Grossiord C, Granier A, Ratcliffe S et al (2014) Tree diversity does not always improve resistance of forest ecosystems to drought. PNAS 111(41):14812-14815

Häberle KH, Weigt R, Nikolova PS et al (2012) Case study "Kranzberger Forst": growth and defence in European beech (Fagus sylvatica L.) and Norway Spruce (Picea abies (L.) Karst). In: Matyssek R et al (eds) Growth and defence in plants, Ecological studies 220. Springer, Berlin, Heidelberg, pp 243-271. https://doi.org/10.1007/978-3-642-30645-7_11 
Hilmers T, Avdagić A, Bartkowicz L et al (2019) The productivity of mixed mountain forests comprised of Fagus sylvatica, Picea abies, and Abies alba across Europe. Forestry. https://doi. org/10.1093/forestry/cpz035

Hoegberg P, Fan H, Quist M et al (2006) Tree growth and soil acidification in response to 30 years of experimental nitrogen loading on boreal forest. Glob Change Biol 12(3):489-499

Hofmann G, Heinsdorf D, Krauss HH (1990) Wirkung atmogener Stickstoffeinträge auf Produktivität und Stabilität von Kiefern-Forstökosystemen. Beiträge für die Forstwirtschaft 24(2):59-73

Joos F (2006) Sekundäre Maßnahmen der Abgasreinigung. In: Technische Verbrennung: Verbrennungstechnik, Verbrennungsmodellierung, Emissionen. Springer, Berlin, Heidelberg, pp 711-723

Jüttner O (1955) Eichenertragstafeln. In: Schober R (ed) (1971) Ertragstafeln der wichtigsten Baumarten. JD Sauerländer's Verlag, Frankfurt am Main, pp 12-25, 134-138

Karnosky DF, Werner H, Holopainen T et al (2007) Free-air exposure systems to scale up ozone research to mature trees. Plant Biol 9(02):181-190

Kauppi PE, Posch M, Pirinen P (2014) Large impacts of climatic warming on growth of boreal forests since 1960. PLoS One 9(11):e111340

Keenan TF, Prentice IC, Canadell JG et al (2016) Recent pause in the growth rate of atmospheric $\mathrm{CO} 2$ due to enhanced terrestrial carbon uptake. Nat Commun 7:1-9

Kenk G, Spiecker H, Diener G (1991) Referenzdaten zum Waldwachstum, KfK-PEF 82. Kernforschungszentrum, Karlsruhe, p 59

Kölling C, Knoke T, Schall P et al (2009) Überlegungen zum Risiko des Fichtenanbaus in Deutschland vor dem Hintergrund des Klimawandels. Forstarchiv 80(2):42-54

Landesforstanstalt Eberswalde (2001) Adam Schwappach: Ein Forstwissenschaftler und sein Erbe. Nimrod Verlag, Hanstedt, p 448

Lapenis A, Shvidenko A, Shepaschenko D et al (2005) Acclimation of Russian forests to recent changes in climate. Glob Change Biol 11(12):2090-2102

Lévesque M, Saurer M, Siegwolf R et al (2013) Drought response of five conifer species under contrasting water availability suggests high vulnerability of Norway spruce and European larch. Glob Change Biol 19(10):3184-3199

Liang J, Crowther TW, Picard N et al (2016) Positive biodiversity-productivity relationship predominant in global forests. Science 354(6309):1-12

Lloret F, Keeling EG, Sala A (2011) Components of tree resilience: effects of successive lowgrowth episodes in old ponderosa pine forests. Oikos 120(12):1909-1920

Lundström US, Bain DC, Taylor AF et al (2003) Effects of acidification and its mitigation with lime and wood ash on forest soil processes: a review. Water Air Soil Pollut Focus 3(4):5-28

Martin-StPaul NK, Limousin JM, Vogt-Schilb H et al (2013) The temporal response to drought in a Mediterranean evergreen tree: comparing a regional precipitation gradient and a throughfall exclusion experiment. Glob Change Biol 19(8):2413-2426

Marziliano P, Tognetti R, Lombardi F (2019) Is tree age or tree size reducing height increment in Abies alba Mill. at its southernmost distribution limit? Ann For Sci 76:17

Matyssek R, Sandermann H (2003) Impact of ozone on trees: an ecophysiological perspective. In: Progress in botany. Springer, Berlin, Heidelberg, pp 349-404

Matyssek R, Wieser G, Ceulemans R et al (2010) Enhanced ozone strongly reduces carbon sink strength of adult beech (Fagus sylvatica) - resume from the free-air fumigation study at Kranzberg Forest. Environ Pollut 158(8):2527-2532

McMahon SM, Parker GG, Miller DR (2010) Evidence for a recent increase in forest growth. Proc Natl Acad Sci USA 107(8):3611-3615

Milnik A (1999) Bernhard Danckelmann. Leben und Leistungen eines Forstmannes. Nimrod Verlag, Suderburg, p 352

Mutke S, Gordo J, Chambel MR et al (2010) Phenotypic plasticity is stronger than adaptative differentiation among Mediterranean stone pine provenances. For Syst 19:354

Nabuurs GJ et al (2013) First signs of carbon sink saturation in European forest biomass. Nat Clim Chang 3:792-796 
Nagel J, Spellmann H, Pretzsch H (2012) Zum Informationspotenzial langfristiger forstlicher Versuchsflächen und periodischer Waldinventuren für die waldwachstumskundliche Forschung. Allg For Jagdztg 183(5/6):111-116

Niinemets Ü, Valladares F (2006) Tolerance to shade, drought, and waterlogging of temperate northern Hemisphere trees and shrubs. Ecol Monogr 76(4):521-547

Piao S, Cui M, Chen A et al (2011) Altitude and temperature dependence of change in the spring vegetation green-up date from 1982 to 2006 in the Qinghai-Xizang Plateau. Agric For Meteorol 151(12):1599-1608

Pretzsch H, Kölbel M (1988) Einfluß von Grundwasserabsenkungen auf das Wuchsverhalten der Kiefernbestände im Gebiet des Nürnberger Hafens - Ergebnisse ertragskundlicher Untersuchungen auf der Weiserflächenreihe Nürnberg 317. Forstarchiv 59(3):89-96

Pretzsch H, Schütze G (2018) Growth recovery of mature Norway spruce and European beech from chronic O3 stress. Eur J For Res 137(2):251-263

Pretzsch H, Dieler J, Matyssek R et al (2010) Tree and stand growth of mature Norway spruce and European beech under long-term ozone fumigation. Environ Pollut 158(4):1061-1070

Pretzsch H, Schütze G, Uhl E (2013) Resistance of European tree species to drought stress in mixed versus pure forests: evidence of stress release by inter-specific facilitation. Plant Biol 15:483-495

Pretzsch H, Biber P, Schütze G et al (2014a) Forest stand growth dynamics in Central Europe have accelerated since 1870. Nat Commun 5(4957):1-10

Pretzsch H, Rötzer T, Matyssek R et al (2014b) Mixed Norway spruce (Picea abies [L] Karst) and European beech (Fagus sylvatica [L]) stands under drought: from reaction pattern to mechanism. Trees 28(5):1305-1321

Pretzsch H, Biber P, Uhl E et al (2015) Long-term stand dynamics of managed spruce-fir-beech mountain forests in Central Europe: structure, productivity and regeneration success. Forestry 88(4):407-428

Pretzsch H, Biber P, Uhl E et al (2017) Climate change accelerates growth of urban trees in metropolises worldwide. Sci Rep 7:10. https://doi.org/10.1038/s41598-017-14831-w

Pretzsch H, Schütze G, Biber P (2018) Drought can favour the growth of small in relation to tall trees in mature stands of Norway spruce and European beech. For Ecosyst 5(1):20. https://doi. org/10.1186/s40663-018-0139-x

Pretzsch H, del Rio M, Biber P et al (2019a) Maintenance of long-term experiments for unique insights into forest growth dynamics and trends: review and perspectives. Eur J For Res 138(1):165-185

Pretzsch H, Steckel H, Heym M et al (2019b) Stand growth and structure of mixed-species and monospecific stands of Scots pine (Pinus sylvestris L) and oak (Quercus robur L, Quercus petraea (MATT) LiEBL) analysed along a productivity gradient through Europe. Eur J For Res. https://doi.org/10.1007/s10342-019-01233-y

Pretzsch H, Grams T, Häberle KH et al (2020a) Growth and mortality of Norway spruce and European beech in monospecific and mixed-species stands under natural episodic and experimentally extended drought. Results of the KROOF rainfall exclusion experiment. Trees Struct Funct. https://doi.org/10.1007/s00468-020-01973-0

Pretzsch H, Hilmers T, Biber P, Avdagić A et al (2020b) Evidence of elevation-specific growth changes of spruce, fir and beech in European mixed-mountain forests during the last three centuries. Can J For Res. https://doi.org/10.1139/cjfr-2019-0368

Pretzsch H, Ammer C, Wolff B et al (2020c) Zuwachsniveau, Zuwachstrend und episodische Zuwachseinbrüche. Ein zusammenfassendes Bild vom aktuellen Zuwachsgang in Rein- und Mischbeständen aus Fichte, Kiefer, Buche und Eiche. Allg For Jagdztg 192:1

Pugh TAM et al (2019) Role of forest regrowth in global carbon sink dynamics. Proc Natl Acad Sci USA 116:4382-4387

Reich PB, Sendall KM, Stefanski A et al (2016) Boreal and temperate trees show strong acclimation of respiration to warming. Nature 531(7596):633 
Rico L, Ogaya R, Barbeta A et al (2014) Changes in DNA methylation fingerprint of Quercus ilex trees in response to experimental field drought simulating projected climate change. Plant Biol 16(2):419-427

Rodríguez-Calcerrada J, Pérez-Ramos IM, Ourcival JM et al (2011) Is selective thinning an adequate practice for adapting Quercus ilex coppices to climate change? Ann For Sci 68(3):575

Rötzer T, Biber P, Moser A et al (2017) Stem and root diameter growth of European beech and Norway spruce under extreme drought. For Ecol Manag 406:184-195

Ruiz-Benito P, Madrigal-Gonzalez J, Ratcliffe S et al (2014) Stand structure and recent climate change constrain stand basal area change in European forests: a comparison across boreal, temperate, and Mediterranean biomes. Ecosystems 17(8):1439-1454

Santopuoli G, Temperli C, Alberdi I et al (2021) Pan-European sustainable forest management indicators for assessing Climate-Smart Forestry in Europe. Can J For Res. https://doi. org/10.1139/cjfr-2020-0166

Schober R (1967) Buchen-Ertragstafel für mäßige und starke Durchforstung. In: Schober R (1972) Die Rotbuche 1971. Schr Forstl Fak Univ Göttingen u Niedersächs Forstl Versuchsanst 43/44, JD Sauerländer's Verlag, Frankfurt am Main, p. 333

Schweingruber FH (2012) Tree rings: basics and applications of dendrochronology. Springer, Berlin, Heidelberg

Shanker AK, Maheswari M, Yadav SK et al (2014) Drought stress responses in crops. Funct Integr Genomics 14(1):11-22

Sitch S, Cox PM, Collins WJ et al (2007) Indirect radiative forcing of climate change through ozone effects on the land-carbon sink. Nature 448(7155):791-794

Sohn JA, Saha S, Bauhus J (2016) Potential of forest thinning to mitigate drought stress: a metaanalysis. For Ecol Manag 380:261-273

Spiecker H, Mielikäinen K, Köhl M, Skovsgaard JP (eds) (1996) Growth trends in European forests, Europ For Inst, Res Rep 5. Springer, Berlin, Heidelberg, p 372

Thurm EA, Uhl E, Pretzsch H (2016) Mixture reduces climate sensitivity of Douglas-fir stem growth. For Ecol Manag 376:205-220

Tognetti R, Lombardi F, Lasserre B et al (2014) Tree-ring stable isotopes reveal twentieth-century increases in water-use efficiency of Fagus sylvatica and Nothofagus spp. in Italian and Chilean mountains. PLoS One 9:e113136

Tognetti R, Lasserre B, Di Febbraro M et al (2019) Modeling regional drought-stress indices for beech forests in Mediterranean mountains based on tree-ring data. Agric For Meteorol 265:110-120

Uhl E, Ammer C, Spellmann H et al (2013) Zuwachstrend und Stressresilienz von Tanne und Fichte im Vergleich. Allg For Jagdztg 184(11/12):278-292

Vayreda J, Martinez-Vilalta J, Gracia M et al (2012) Recent climate changes interact with stand structure and management to determine changes in tree carbon stocks in Spanish forests. Glob Change Biol 18(3): 1028-1041

Verhoeven KJ, Vonholdt BM, Sork VL (2016) Epigenetics in ecology and evolution: what we know and what we need to know. Mol Ecol 25(8):1631-1638

Walentowski H, Kölling C, Ewald J (2007) Die Waldkiefer - bereit für den Klimawandel? LWF Wissen 57:37-46

Wiedemann E (1936/1942) Die Fichte 1936, vol 248. Verlag M \& H Schaper, Hannover

Wiedemann E (1943) Kiefern-Ertragstafel für mäßige Durchforstung, starke Durchforstung und Lichtung. In: Wiedemann E (1948) Die Kiefer 1948. Verlag M \& H Schaper, Hannover, p 337

Wipfler P, Seifert T, Heerdt C et al (2005) Growth of adult Norway Spruce (Picea abies [L.] Karst.) and European beech (Fagus sylvatica [L.]) under free-air ozone fumigation. Plant Biol 7(6):611-618

Wittig VE, Ainsworth EA, Naidu SL et al (2009) Quantifying the impact of current and future tropospheric ozone on tree biomass, growth, physiology and biochemistry: a quantitative metaanalysis. Glob Change Biol 15(2):396-424 
Zang C, Rothe A, Weis W et al (2011) Zur Baumarteneignung bei Klimawandel: Ableitung der Trockenstress-Anfälligkeit wichtiger Waldbaumarten aus Jahrringbreiten. Environ Sci Pol 14:100-110

Zang C, Pretzsch H, Rothe A (2012) Size-dependent responses to summer drought in Scots pine, Norway spruce and common oak. Trees 26(2):557-569

Zapater M, Hossann C, Bréda N et al (2011) Evidence of hydraulic lift in a young beech and oak mixed forest using 180 soil water labelling. Trees 25:885-894

Zhu K, Zhang J, Niu S et al (2018) Limits to growth of forest biomass carbon sink under climate change. Nat Commun 9:2709

Open Access This chapter is licensed under the terms of the Creative Commons Attribution 4.0 International License (http://creativecommons.org/licenses/by/4.0/), which permits use, sharing, adaptation, distribution and reproduction in any medium or format, as long as you give appropriate credit to the original author(s) and the source, provide a link to the Creative Commons license and indicate if changes were made.

The images or other third party material in this chapter are included in the chapter's Creative Commons license, unless indicated otherwise in a credit line to the material. If material is not included in the chapter's Creative Commons license and your intended use is not permitted by statutory regulation or exceeds the permitted use, you will need to obtain permission directly from the copyright holder. 